This is the accepted manuscript. It is published by ASCE Library and can be found online at https:// doi.org/10.1061/9780784414422.ch14 


\title{
Agricultural By-Products for Phosphorous Removal and Recovery from Water and Wastewater: A Green Technology
}

\author{
Huu Hao Ngo, Wenshan Guo, Thi An Hang Nguyen, Rao Surampalli and \\ Tian Zhang
}

\subsection{Introduction}

Phosphorus (P) is a critical nutrient for the plant growth (Mezenner and Bensmaili 2009). In addition, as a component of DNA, RNA, ATP, phospholipids, P plays an important role in animal lives (Karachalios 2012). Furthermore, P is one of the principal materials for many industries, such as fertilizer, pesticide, steel production, etc. (Choi et al. 2012). The excessive amount of $\mathrm{P}$ in aquatic medium may originate from natural sources (e.g. precipitation, soil erosion, decomposition of organic matters) and/or artificial sources (e.g. mining, fertilizers, detergents, human and animal excreta). Karachalios (2012) claims that the agricultural runoffs contribute more than $50 \%$ to the freshwater eutrophication. The level of $\mathrm{PO}_{4}-\mathrm{P}$ in municipal wastewater is in the range of $4-15 \mathrm{mg} / \mathrm{L}$, while it may exceed $10 \mathrm{mg} / \mathrm{L}$ in industrial wastewater (Peleka and Deliyanni 2009). According to Biswas (2008), each person discharges $2-3$ g P into domestic wastewater via feces and urine per day. The concentration of $\mathrm{P}$ in receiving water bodies greater than $0.02 \mathrm{mg} / \mathrm{L}$ may induce eutrophication (Ismail 2012; Mallampati and Valiyaveetttil 2013). This phenomenon leads to the depletion of oxygen in aquatic medium, thus threatening the aquatic lives (Jyothi et al. 2012). To prevent aquatic medium from eutrophication, United States Environmental Protection Agency recommended that the $\mathrm{PO}_{4}{ }^{3-}$ levels should not be higher than $0.05 \mathrm{mg} / \mathrm{L}$ if streams discharge into lakes or reservoirs (Benyoucef and Amrani 2011; Ismail 2012). To meet more stringent environmental regulations, the removal of P from water and wastewater is necessary (Kalmykova and Fedje 2013). Also, there was a warning that the global existing rock P reserves could be depleted in 50-100 years (Ogata et al. 2012; Eljamal et al. 2013). Due to increasing scarcity of natural $\mathrm{P}$ ores, the $\mathrm{P}$ recovery from water and wastewater has recently become a matter of urgent (Anirudhan et al. 2006; Zhang et al. 2012). 
Understanding different forms of $\mathrm{P}$ in aqueous solutions enables an appropriate selection of treatment technologies (Neethling 2011). Though, in natural water bodies, $\mathrm{P}$ can exist in different forms (Figure 14.1), only orthophosphate can accelerate the algae growth, inducing the eutrophication (Bhojappa 2009). Depending on $\mathrm{pH}$ values of the aquatic medium, orthophosphate may exist in various species. In strongly alkaline conditions, $\mathrm{PO}_{4}{ }^{3-}$ is the main form, whilst in weakly alkaline conditions, $\mathrm{HPO}_{4}{ }^{2-}$ is dominant. In weekly acidic conditions, $\mathrm{H}_{2} \mathrm{PO}_{4}^{-}$prevails, whereas $\mathrm{H}_{3} \mathrm{PO}_{4}$ is most common in strong acidic conditions (Karachalios 2012).

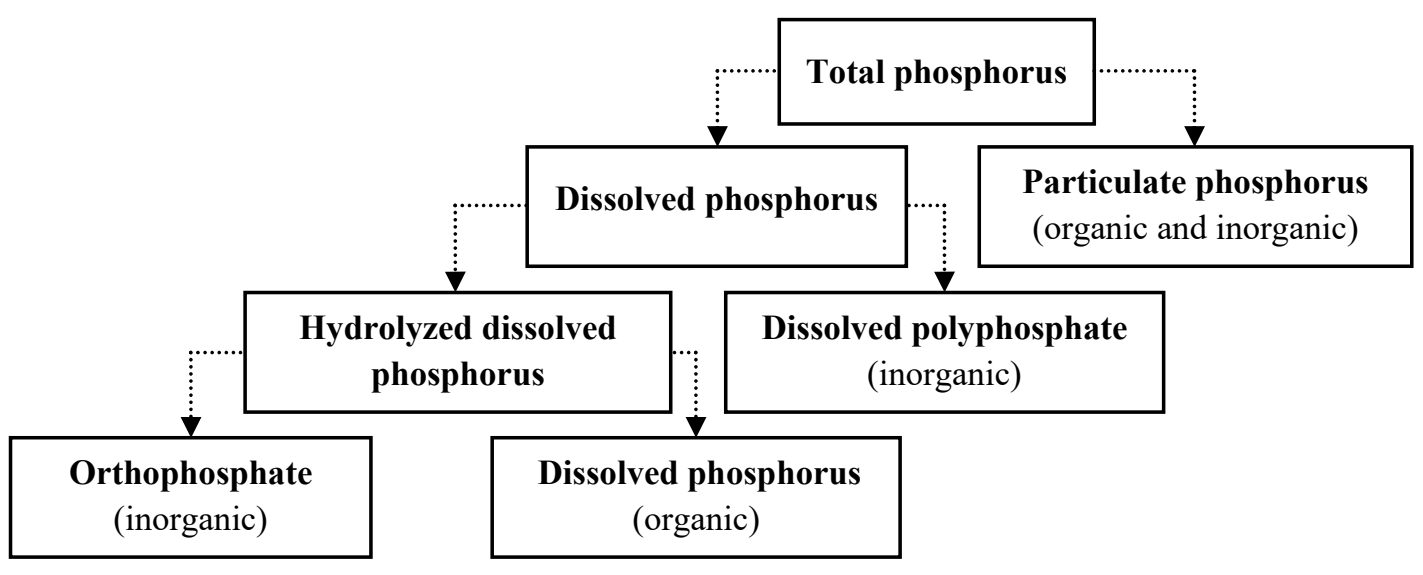

Figure 14.1. Different forms of phosphorus in aqueous solutions

Until now, various technologies are available for controlling $\mathrm{PO}_{4}{ }^{3-}$ pollution. These processes can be classified as chemical methods (precipitation, crystallization, anion exchanger, and adsorption), biological methods (assimilation, enhanced biological phosphorus removal, land treatment system, constructed wetlands), and physical methods (microfiltration, reverse osmosis, electrodialysis, and magnetic separation) (Hu et al., 2005; Zhang et al. 2007; Bhojappa 2009; Benyoucef and Amrani 2011). Of these methods, chemical precipitation and biological processes are most commonly used. However, each method represents its own demerits (Table 14.1). The chemical precipitation is often prone to high chemical expense, effluent neutralization requirement, inadequate efficiency for dilute $\mathrm{P}$ solutions, etc. (Kumar et al. 2010; Zhang et al. 2011; Mallampati and Valiyaveetttil 2013). Similarly, the biological process associated with activated sludge systems suffers from drawbacks, such as low removal efficiency $(\leq 30 \%)$, complicated operation, high energy consumption and footprint (Ning et al. 2008; Peleka and Deliyanni 2009). On the other hand, adsorption is proven to be affordable, effective and best suited for low levels of $\mathrm{PO}_{4}{ }^{3-}$ (Li et al. 2009; Zhang et al. 2011). Notably, this method is believed to have an advantage when used for $\mathrm{P}$ recovery, owing to the selective $\mathrm{P}$ adsorption capability (Loganathan et al. 2014). Previously, activated carbon or anion exchanger resins are commonly used for P decontamination. However, the problems associated with high cost, no renewability and disposal after use hinder their widespread application in developing countries (Karthikeyan et al. 2004). Hence, increasing 
attention has been paid to agricultural by-products (AWBs) in an attempt to search for a viable alternative option (Jyothi et al. 2012). It is desirable to develop AWBs that have low cost, high effectiveness, good selectivity, potential renewability, and high adaptability to various process parameters (Ning et al. 2008).

Table 14.1. Comparison of different technologies for phosphorous removal ${ }^{\mathrm{a}}$

\begin{tabular}{|c|c|c|c|}
\hline Methods & $\begin{array}{l}\text { Effluent } \\
\text { features }\end{array}$ & Advantages & Disadvantages \\
\hline $\begin{array}{l}\text { Chemical } \\
\text { precipitation }\end{array}$ & $\begin{array}{l}\text { EPC: } \\
0.005-0.04\end{array}$ & $\begin{array}{ll}\text { - } & \text { Easy to install } \\
\text { - } & \text { Flexible } \\
\text { - } & \text { High P removal } \\
\text { efficiency } \\
\text { - } & \text { Less space }\end{array}$ & $\begin{array}{l}\text { - Inappropriate for wastewater } \\
\text { with low P concentrations } \\
\text { - High cost for chemicals } \\
\text { - Chemical sludge generation } \\
\text { - Neutralization of effluent } \\
\text { - Do not recycle P } \\
\text { - Cannot meet strict regulations }\end{array}$ \\
\hline Crystallization & EPC: $0.3-1.0$ & $\begin{array}{l}\text { - Final product can } \\
\text { be used as a } \\
\text { fertilizer without } \\
\text { further processing }\end{array}$ & $\begin{array}{l}\text { - Chemicals and operation skills } \\
\text { are necessary } \\
\text { - Complex process } \\
\text { - Increased salinity }\end{array}$ \\
\hline $\begin{array}{l}\text { Biological P } \\
\text { removal }\end{array}$ & $\begin{array}{l}\mathrm{EPC}: 0.1-0.3 \\
\mathrm{RE}<30\end{array}$ & $\begin{array}{l}\text { - Avoiding chemical } \\
\text { use } \\
\text { - Potential P } \\
\text { recovery }\end{array}$ & $\begin{array}{l}\text { - } \text { More complex technology } \\
\text { - Low removal efficiency } \\
(10-30 \%) \\
\text { - Biological sludge handling } \\
\text { - External carbon source may be } \\
\text { required } \\
\text { - Sensitive to changes in } \\
\text { temperature and P load } \\
\text { (min. } 0.02 \mathrm{mgP} / \mathrm{L} \text { is } \\
\text { required) } \\
\text { - Inefficient P recovery } \\
\text { - Cannot meet strict regulations }\end{array}$ \\
\hline $\begin{array}{l}\text { Enhanced } \\
\text { biological P } \\
\text { removal }\end{array}$ & $\begin{array}{l}0.02 \leq \mathrm{EPC}< \\
0.1, \\
\text { depending on } \\
\text { duration } \\
\text { RE: } 100\end{array}$ & $\begin{array}{l}\text { - } \text { Can remove P to } \\
\text { very low levels } \\
\text { - Modest cost } \\
\text { - Minimal sludge } \\
\text { production }\end{array}$ & $\begin{array}{l}\text { - More energy consumption } \\
\text { - More space }\end{array}$ \\
\hline $\begin{array}{l}\text { Constructed } \\
\text { wetlands }\end{array}$ & $\begin{array}{l}\text { EPC: } 0.02 \text {; } \\
\text { RE: } 39-99 \text {, } \\
\text { depending on } \\
\text { plant type }\end{array}$ & $\begin{array}{l}\text { - Low cost } \\
\text { - Low technology }\end{array}$ & - Sediments \\
\hline $\begin{array}{l}\text { Magnetic } \\
\text { separation }\end{array}$ & EPC: $0.1-0.5$ & $\begin{array}{l}\text { - High P removal } \\
\text { - Low power input }\end{array}$ & $\begin{array}{l}\text { - Chemicals required } \\
\text { - Technology is complex }\end{array}$ \\
\hline
\end{tabular}


Table 14.1. Continued

\begin{tabular}{|c|c|c|c|}
\hline Methods & Effluent features & Advantages & Disadvantages \\
\hline $\begin{array}{l}\text { Membrane } \\
\text { technology }\end{array}$ & $\begin{array}{l}\text { EPC: } 0.04 \text { (MBRs, } \\
\text { Tertiary } \\
\text { membrane } \\
\text { filtration); } 0.008 \\
\text { (RO); } \\
<0.005 \text { (Electro } \\
\text { dialysis) }\end{array}$ & - & $\begin{array}{l}\text { - High capital \& } \\
\text { operation cost }\end{array}$ \\
\hline $\begin{array}{l}\text { Ion } \\
\text { exchange }\end{array}$ & & $\begin{array}{l}\text { - Simple operation } \\
\text { - Adaptability to various } \\
\text { solution compositions } \\
\text { and flow rates } \\
\text { - High P removal } \\
\text { - Struvite produced can be } \\
\text { used in agriculture }\end{array}$ & $\begin{array}{l}\text { - High capital \& } \\
\text { operation cost } \\
\text { - Complex technology } \\
\text { - Chemicals required } \\
\text { - Low selectivity } \\
\text { - Materials originated } \\
\text { from nonrenewable } \\
\text { resources }\end{array}$ \\
\hline Adsorption & $\begin{array}{l}\text { EPC: } 0.005-0.01 \\
\mathrm{RE}>80\end{array}$ & $\begin{array}{l}\text { - Simple operation } \\
\text { - Cost-effectiveness } \\
\text { - Recommended for low P } \\
\text { concentration wastewater } \\
\text { - Few chemicals involved } \\
\text { - Without additional } \\
\text { sludge } \\
\text { - Potential P recovery } \\
\text { - Multiple regeneration of } \\
\text { adsorbents }\end{array}$ & $\begin{array}{l}\text { - Experimental } \\
\text { technology } \\
\text { - High cost } \\
\text { - Disposal problems } \\
\text { after use }\end{array}$ \\
\hline
\end{tabular}

Note: $\mathrm{EPC}=$ Effluent phosphorous concentration $(\mathrm{mgP} / \mathrm{L}) ; \mathrm{RE}=$ Removal efficiency (\%).

There is growing interest in the use of AWBs for P removal/recovery. There are many reasons accounting for this (Figure 14.2). Firstly, this practice can prevent surface water from eutrophication, owing to the production of cleaner effluents, reduction of $\mathrm{P}$ pollution caused by mining activities, and mitigation of $\mathrm{P}$ leaching and runoff. Secondly, huge amounts of agricultural wastes generated worldwide represent an environmental burden. The recycling wastes to control $\mathrm{PO}_{4}{ }^{3-}$ pollution provides a viable option to reduce wastes in a low cost and green way (Tshabalala et al. 2004; Ismail 2012; Eljamal et al. 2013). This also fits well with one of the 12 principles of Green Chemistry, i.e. "use of renewable resources" (Srivastava and Goyal 2010). In addition, the successful exploitation of $\mathrm{P}$ from wastewater will diminish the use of mineral $\mathrm{P}$, and thus saving exhausting $\mathrm{P}$ rock reserves. Moreover, a large amount of anion exchanger resins created from abundant, cheap and renewable materials may help to fill a need for innovative, inexpensive and efficient method for $\mathrm{PO}_{4}{ }^{3-}$ removal. Consequently, the cost of water treatment will be reduced (Liu et al. 2012). Eventually, by converting waste into fertilizers and useful materials for water treatment, this practice may create revenues (Huang et al. 2010; Peng et al. 2012). Apparently it may provide a sustainable, efficient and profit regenerating solution for 
P management (Kuzma 2011). For these reasons, this practice should be considered as a promising green technology.

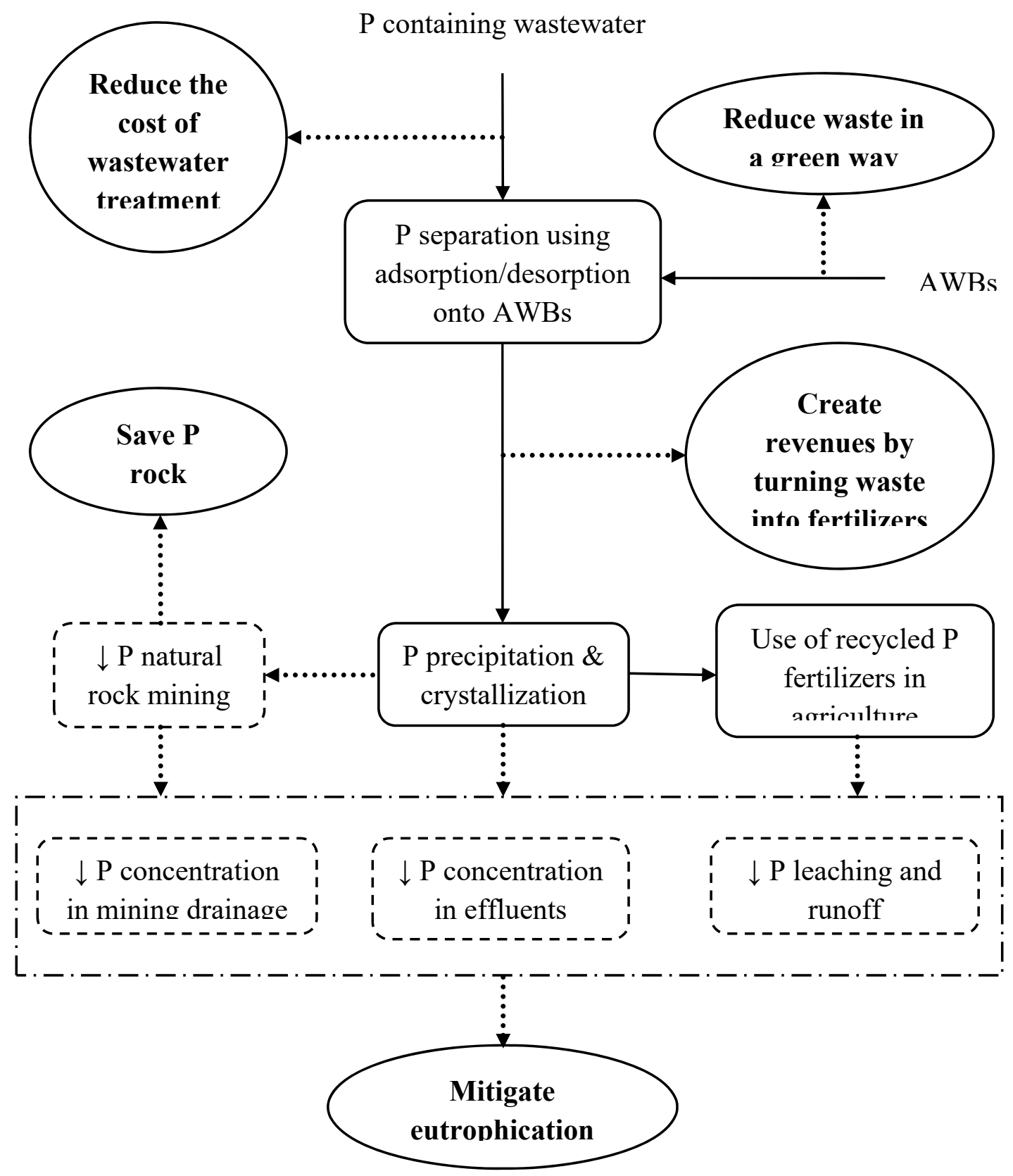

Figure 14.2. The benefits of using AWBs for P removal/recovery from wastewater

This chapter focuses on the fundamental and applied aspects of the removal/recovery of $\mathrm{PO}_{4}{ }^{3-}$ from water and wastewater using AWBs. Part I (Section 14.2) provides new insights into adsorption and desorption mechanisms. In addition, it refers to the effect of process parameters. Part II (Section 14.3) evaluates the 
adsorption performance of AWBs in both natural and modified forms. Also, this section mentions the recovery process of $\mathrm{PO}_{4}{ }^{3-}$ using $\mathrm{AWBs}$ in terms of drivers, technologies, and barriers. Part III (Sections 14.4 and 14.5) summarizes the recent developments and proposes the future work.

\subsection{Process Fundamentals}

\subsubsection{Mechanistic Aspects of Phosphorus Sorption Process}

Insights in sorption mechanisms are necessary for optimizing the sorption process. Due to the complexity of these processes, various information ( $\mathrm{pH}$ profile, desorption, kinetic, activation energy, etc.) and techniques (FTIR, XRD, TEM, etc.) have been used. The reported types of adsorption of $\mathrm{PO}_{4}{ }^{3-}$ by $\mathrm{AWBs}$ include ion exchange, ligand exchange, surface precipitation, and diffusion.

\subsubsection{Ion Exchange}

This mechanism is considered as physical adsorption (electrostatic attraction). It is associated with very fast, weak and reversible adsorption, which occurs through the outer-sphere complex. This replaces any ion on the surface of an ion exchanger by a chemically equal number of another ion while preserving the electroneutrality of the ion exchanger (Loganathan et al. 2014). The ion exchange mechanism can be found in many studies removing P by AWBs, such as banana stem (Anirudhan et al. 2006); wood residues (Karachalios 2012); giant reed (Xu et al. 2011a); etc. A typical method to predict the type of adsorption is based on the activation energy (E) magnitude. While $\mathrm{E}$ values in the range of $8-16 \mathrm{~kJ} / \mathrm{mol}$ represents the chemical adsorption, $\mathrm{E}$ values lower than $8 \mathrm{~kJ} / \mathrm{mol}$ stand for physical adsorption. The $\mathrm{E}$ values for the sorption of $\mathrm{P}$ onto modified wheat residue, modified sawdust and calcined waste eggshell were found to be $3.393 .088,0.4 \mathrm{~kJ} / \mathrm{mol}$, respectively. This implies that physical adsorption might be dominant sorption mechanism in these cases (Xu et al. 2009; Benyoucef and Amrani 2011; Kose and Kivanc 2011). Based on the effect of $\mathrm{pH}$, Anirudhan et al. (2006) concluded that in the $\mathrm{pH}$ range of 5.0-7.0, the removal of $\mathrm{P}$ by quaternized banana stem could mainly be attributed to ion exchange between $\mathrm{Cl}^{-}$ of quaternary mine group and $\mathrm{HPO}_{4}^{2-} / \mathrm{H}_{2} \mathrm{PO}_{4}^{-}$in the solution as follows:

$$
\begin{aligned}
& 2 \mathrm{BS}-\mathrm{CH}_{2}-\mathrm{N}^{+} \mathrm{H}\left(\mathrm{CH}_{3}\right)_{2} \mathrm{Cl}^{-}+\mathrm{HPO}_{4}{ }^{2-} \rightarrow\left[\mathrm{BS}-\mathrm{CH}_{2}-\mathrm{N}^{+} \mathrm{H}\left(\mathrm{CH}_{3}\right)_{2}\right]_{2} \mathrm{HPO}_{4}{ }^{2-}+2 \mathrm{Cl}^{-}
\end{aligned}
$$

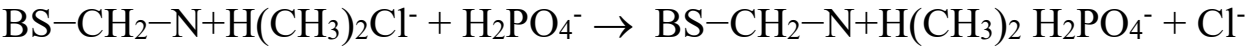

Similarly, Xu et al. (2011a) proposed that the ion exchange could be an important pathway for the remediating $\mathrm{P}$ by modified giant reed. The replacement of chloride ions in the amine groups of quaternized giant reed by phosphate ions in the solution could occur as follows:

$$
\mathrm{R}^{\prime}-\mathrm{N}+\left(\mathrm{CH}_{2} \mathrm{CH}_{3}\right)_{3} \ldots \mathrm{Cl}^{-}+\mathrm{H}_{2} \mathrm{PO}_{4}^{-} \rightarrow \mathrm{R}^{\prime}-\mathrm{N}+\left(\mathrm{CH}_{2} \mathrm{CH}_{3}\right)_{3} \ldots \mathrm{H}_{2} \mathrm{PO}_{4}^{-}+\mathrm{Cl}^{-}
$$


From FTIR results, De Lima et al. (2012) suggested that the modification of coconut shell fibers with ammonium quaternary salt led to the integration of $-\mathrm{NH}_{2}$ groups into the material. Consequently, the removal of $\mathrm{P}$ by quaternized coconut shell fibers occurred mainly via electrostatic interactions between $-\mathrm{NH}_{2}$ groups and $\mathrm{PO}_{4}{ }^{3-}$ anions.

\subsubsection{Ligand Exchange}

This is considered as chemical sorption, which is characterized by fast, strong and less reversible adsorption with reduced zero point charges. It may happen through the inner sphere complex, when $\mathrm{PO}_{4}{ }^{3-}$ anions create a covalent chemical bond with a metallic cation on the surface of AWBs, leading to the liberation of other anions, which formerly attached to the metallic cation (Loganathan et al. 2014). This mechanism was reported for the case of decontaminating $\mathrm{P}$ by natural and iron impregnated coir pith (Krishnan and Haridas 2008). The authors suggested that in the $\mathrm{pH}$ range of 2.0-3.5, the ligand exchange occurred between $\mathrm{H}_{2} \mathrm{PO}_{4}{ }^{-}$ions and surface $\mathrm{OH}^{-}$groups to form inner-sphere complexation as follows:

$$
\begin{gathered}
\mathrm{CP}-\mathrm{OH}+\mathrm{H}_{2} \mathrm{PO}_{4}^{-} \underset{\mathrm{H}^{+}}{\stackrel{\mathrm{H}}{\rightarrow}} \mathrm{CP}-\left(\mathrm{H}_{2} \mathrm{PO}_{4}\right)+\mathrm{H}_{2} \mathrm{O} \\
\mathrm{CP}-\mathrm{Fe}(\mathrm{OH})+\mathrm{H}_{2} \mathrm{PO}_{4}^{-} \rightarrow \mathrm{CP}-\mathrm{Fe}\left(\mathrm{H}_{2} \mathrm{PO}_{4}\right)+\mathrm{H}_{2} \mathrm{O}
\end{gathered}
$$

Likewise, based on the effect of $\mathrm{pH}$, Biswas (2007) concluded that the adsorption of $\mathrm{P}$ by metal loaded orange waste (SOW) gels was possibly due to ligand exchange mechanism between $\mathrm{PO}_{4}{ }^{3-}$ ions and $\mathrm{OH}^{-}$ions coordinated on the metal ions impregnated on the orange waste gels (Schemes $14.1 \& 14.2$ ). The authors suggested that loaded metal ions could be readily converted into hydrated forms e.g. $\left[\mathrm{Ln}\left(\mathrm{H}_{2} \mathrm{O}\right)_{n}\right]^{3+}$, $\left[\mathrm{Zr}_{4}(\mathrm{OH})_{8}\left(\mathrm{H}_{2} \mathrm{O}\right)_{16}\right]^{8+}$, and $\left[\mathrm{Zr}_{8}(\mathrm{OH})_{20}\left(\mathrm{H}_{2} \mathrm{O}\right)_{24}\right]^{12+}$ species with the abundant amount of $\mathrm{OH}^{-}$ions and $\mathrm{H}_{2} \mathrm{O}$ molecules. The $\mathrm{H}_{2} \mathrm{O}$ molecules were deprotonated by releasing $\mathrm{H}^{+}$ions to form $\mathrm{OH}^{-}$ions, which could be replaced by $\mathrm{PO}_{4}{ }^{3-}$ ions via the ligand exchange mechanism.

\subsubsection{Surface Precipitation}

When the concentration of components of the precipitate surpasses the solubility product of the precipitate, the precipitation of $\mathrm{P}$ with metallic ions may take place on the surface of AWBs. This mechanism is described as fast and hardly reversible adsorption. Using the X-ray diffraction (XRD) and Fourier transform infrared spectroscopy (FTIR) results, Shin et al. (2005) verified the contribution of surface precipitation to the $\mathrm{PO}_{4}{ }^{3-}$ binding onto $\mathrm{La}(\mathrm{III})$ loaded bark fiber. Based on kinetic studies, Namasivayam et al. (2005) concluded that the removal of P by oyster shell powder (OSP) was probably through precipitation of $\mathrm{P}$ as calcium phosphate and then turned into hydroxyapatite on the surface of OSP.
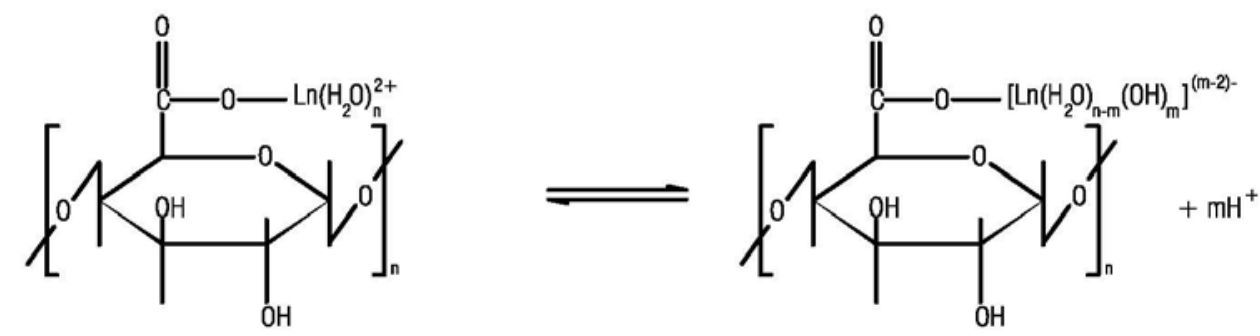
Scheme 14.1. Formation of exchangeable hydroxyl ions during hydrolysis, where $\mathrm{m}$ $=1$ or 2; Ln stands for $\mathrm{La}(\mathrm{III}), \mathrm{Ce}(\mathrm{III}), \mathrm{Fe}(\mathrm{III})$ (Biswas et al. 2007)
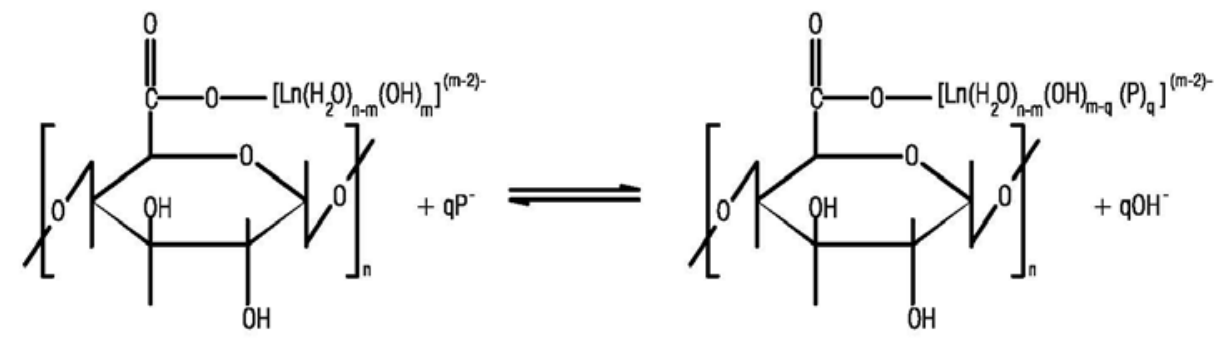

Scheme 14.2. Ligand exchange reaction, where $\mathrm{q}=1$ or 2 and $\mathrm{P}$ represents phosphate anion (Biswas et al. 2007)

\subsubsection{Intraparticle Diffusion}

This process is known as physical sorption, which takes place inside pores and cavities of AWBs. It is characterized by irreversible and very slow adsorption, which may last for days to months (Loganathan et al. 2014). If intraparticle diffusion mechanism prevails, a plot between the $\mathrm{PO}_{4}{ }^{3-}$ adsorption capacity and the square root of the contact time should be a straight line passing through the origin. The relationship attained in a study by Karachalios (2012) was non-linear. That clearly indicated that intra-particle diffusion could not play a major role in the sorption of $\mathrm{PO}_{4}{ }^{3-}$ onto quarternized wood residues. Based on Transmission electron microscopy (TEM) results, Riahi et al. (2009) suggested that intra-particle diffusion led to the accumulation of $\mathrm{PO}_{4}{ }^{3-}$ into internal cells of date palm fibers.

\subsubsection{Co-existing Mechanisms}

Due to the complex nature of the sorption process using AWBs, it is quite common that the process can be attributed to several mechanisms. Based on the effect of $\mathrm{pH}$ and desorption results, Anirudhan et al. (2006) and Namasivayan and Sangeetha (2004) concluded that ion exchange and chemisorption mechanisms could be important pathways for the removal of $\mathrm{P}$ by quaternized banana stem and $\mathrm{ZnCl}_{2}$ activated carbon, respectively. Tshabalala et al. (2004) observed a reduction in $\mathrm{PO}_{4}{ }^{3-}$ uptake with increasing ionic strength and presence of $\mathrm{SO}_{4}{ }^{2-}, \mathrm{NO}_{3}{ }^{-}$anions. For that reason, they suggested that ion exchange and Lewis acid-base interactions might be responsible for retention of $\mathrm{PO}_{4}{ }^{3-}$ ions onto cationized milled wood residues. From $\mathrm{P}$ surface loading and spectroscopic analysis results, Shin et al. (2005) claimed that ion exchange and surface precipitation could contribute to the elimination of $\mathrm{P}$ by $\mathrm{La}$ (III) 
treated juniper bark fiber. Similary, physisorption and chemisorption mechanisms are found to co-exist in the studies conducted by Mezenner and Bensmaili (2009); Huang et al. (2010); Benyoucef and Amrani (2011). In a more recent study, Karachalios (2012) explored that the adsorption process of $\mathrm{PO}_{4}{ }^{3-}$ onto quaternized pine bark residues resulted from both boundary layer and intra-particle diffusion mechanisms.

\subsubsection{Mechanistic Aspects of Phosphorus Desorption Process}

Desorption plays an important role in enabling the reusability of AWBs and recovery of $\mathrm{P}$. The $\mathrm{P}$ can be efficiently eluted from spent AWBs by distilled water, salts, acids, and bases (Table 14.2).

In an attempt to reduce the cost of chemicals used for desorption and mitigate adverse impacts on the environment, some researchers have used distilled water as an eluent. Namasivayam and Sangeetha (2004) investigated desorption of P from spent $\mathrm{ZnCl}_{2}$ activated coir pith carbon using distilled water at various $\mathrm{pH}$ values (2-11). Desorption was shown to be favored at $\mathrm{pH} 2(30 \%)$ and $\mathrm{pH} 11(50 \%)$, while suppressed in $\mathrm{pH}$ range of $3-11(<10 \%)$. The high desorbability at $\mathrm{pH}$ values $2 \& 11$ was explained by the dissociation constants of phosphate and the dominant phosphate species at different $\mathrm{pH}$ values. At $\mathrm{pH} 2$, unionized $\mathrm{H}_{3} \mathrm{PO}_{4}$ species are dominant. These $\mathrm{P}$ species have low affinity toward the biosorbent, and thus providing favorable conditions for $\mathrm{P}$ desorption. At $\mathrm{pH} 11$, more $\mathrm{OH}^{-}$ions are available in the solution, leading to a stronger competition with $\mathrm{HPO}_{4}{ }^{2-}$ and $\mathrm{PO}_{4}{ }^{3-}$ for binding sites. That was the reason why the efficient desorption was obtained at $\mathrm{pH} 11$. Nevertheless, the maximum desorption efficiency was the relatively low (50\%). This was probably due to the fact that $\mathrm{PO}_{4}{ }^{3-}$ ions were removed by both ion exchange and chemisorptions mechanisms, whereas only $\mathrm{PO}_{4}{ }^{3-}$ ions removed by ion exchanged was desorbed. On the other hand, Mallampati and Valiyaveettil (2013) observed a relatively high desorption capacity (90\%) in very short time (10 min.), when distilled water $\mathrm{pH} 12$ was employed in case of desorbing $\mathrm{P}$ from $\mathrm{Zr}(\mathrm{IV})$ loaded apple peels. The successful desorption of $\mathrm{P}$ at high $\mathrm{pH}$ value was explained by the replacement of $\mathrm{PO}_{4}{ }^{3-}$ on apple peel surface by $\mathrm{OH}^{-}$anions in the solution.

Another means of desorption of $\mathrm{P}$ from AWBs is using neutral salts, e.g. $\mathrm{NaCl}, \mathrm{KCl}$. In some studies, the use of these salts at different concentrations resulted in particularly high desorption efficiencies, e.g. $99.8 \%$ for $\mathrm{NaCl} 0.2 \mathrm{M}$ from quaternized wood residues (Karachalios 2012); $95.4 \%$ for $\mathrm{NaCl} 0.1 \mathrm{M}$ from wheat straw anion exchanger (WS-AE) (Xu et al. 2010); $100 \%$ for $\mathrm{NaCl} 0.1 \mathrm{M}$ from modified giant reed (Xu et al. 2011a). Conversely, very poor desorption capacities could be found in other studies, e.g. $0.7 \%$ for $\mathrm{NaCl} 0.5 \mathrm{M}$ from calcined waste eggshell (Kose and Kivanc 2011); $11.2 \%$ and $13 \%$ for $\mathrm{KCl} 0.01 \mathrm{M}$ from granular date stones and palm surface fibers, respectively (Ismail 2012). Loganathan et al. (2014) suggested that neutral salts were efficient eluents for weak and reversible sorption, where ion exchange could be an important pathway for the removal of P (e.g. Xu et al. 2010, 2011; Karachalios 2012). In contrast, for strong and less reversible sorption, 
which was controlled by such mechanisms as ligand exchange, surface precipitation, or chemisorptions, the efficacy of these salts was usually low (e.g. Kose and Kivanc 2011; Ismail 2012). The higher concentrations of neutral salts seem to favor desorption. A rise in the concentration of $\mathrm{NaCl}$ as an eluent from 0.001 to $0.1 \mathrm{M}$ led to a significant improvement $(48.7 \%)$ in $\mathrm{P}$ desorption efficiency of modified giant reed (Xu et al. 2011a). However, it should be emphasized that the use of neutral salts as desorbents at high concentrations may increase the salinity in arable lands once $\mathrm{P}$ desorbed by this method was recovered and applied as fertilizers (Loganathan et al. 2014). One advantage of desorbing by this method is a minor loss in the adsorption capacity and weight of AWBs after several cycles of operation. For example, the adsorption capacity of was found to decrease by $5.59 \%$ after 5 operation cycles for $\mathrm{NaCl} 0.2 \mathrm{M}$ (Karachalios 2012); 9.58\% after 4 operation cycles for $\mathrm{NaCl} 0.1 \mathrm{M}(\mathrm{Xu}$ et al. 2010). The slight weight loss (1-3\%) was reported when $\mathrm{NaCl} 0.1 \mathrm{M}$ was used for desorption of $\mathrm{P}$ from modified giant reed (Xu et al. 2011a). This property facilitates the reusability of AWBs.

In some cases, to improve desorption efficiency of $\mathrm{P}$, distilled water and neutral salts have been replaced by acids or bases. Among these, $\mathrm{NaOH}$ and $\mathrm{HCl}$ are widely used. $\mathrm{NaOH}$ and $\mathrm{HCl}$ normally demonstrated remarkable desorption capacities. For example, the desorption efficiency was found to be $97.1 \%$ for $\mathrm{NaOH} 0.1 \mathrm{M}$ (Anirudhan et al. 2006); 85\% for $\mathrm{HCl} 0.4 \mathrm{M}$ and 95\% for $\mathrm{NaOH} 0.2 \mathrm{M}$ (Biswas 2008); $97.5 \%$ for $\mathrm{HCl} 0.1 \mathrm{M}$ (Xu et al. 2010); $100 \%$ for $\mathrm{HCl} 0.1 \mathrm{M}$ and $\mathrm{NaOH} 0.1 \mathrm{M}$ (Xu et al. 2011a); 95.6\% for $\mathrm{NaOH} \mathrm{0.05} \mathrm{M} \mathrm{(Zhang} \mathrm{et} \mathrm{al.} \mathrm{2012).} \mathrm{High} \mathrm{efficacy} \mathrm{of}$ acids or bases could be explained by the low affinity of dominant $\mathrm{P}$ species, such as $\mathrm{H}_{3} \mathrm{PO}_{4}$ (in acidic medium), $\mathrm{HPO}_{4}{ }^{2-}$ and $\mathrm{PO}_{4}{ }^{3-}$ (in alkaline medium), toward binding sites on AWBs surface. Another reason for that was the stronger competition in alkaline medium between $\mathrm{OH}^{-}$ions and $\mathrm{PO}_{4}{ }^{3-}$ for binding sites on $\mathrm{AWBs}$. It is worth mentioning studies conducted by Ismail (2012) and Zhang (2012), where the adsorption was controlled by chemisoprtion mechanism. While $\mathrm{KCl} 0.01 \mathrm{M}$ demonstrated very poor desorption capacities $(11.2-13 \%)$, the satisfactory elution was observed for $\mathrm{NaOH} 0.05 \mathrm{M}(95.6 \%)$. This provides strong evidence that, bases are superior to neutral salts in desorbing $\mathrm{P}$ in case of strong sorption. Both $\mathrm{Xu}$ et al. (2011a) and Zhang et al. (2012) found that, higher concentration of $\mathrm{NaOH}$ enabled desorption of $\mathrm{P}$ from spent AWBs. This was probably due to a stronger competition between $\mathrm{OH}^{-}$ions and $\mathrm{PO}_{4}{ }^{3-}$ for binding sites. Though $\mathrm{HCl}$ and $\mathrm{NaOH}$ were proven to be effective eluents, their application could result in some side effects. The loss in the adsorption capacity was shown to be $12 \%$ for $\mathrm{NaOH} 0.1 \mathrm{M}$ (Anirudhan et al. 2006) or $10.53 \%$ for $\mathrm{HCl} 0.1 \mathrm{M}$ (Xu et al. 2010). Particularly, the complete loss of the adsorption capacity of modified coconut shell fibers was recorded after the second cycle of reuse. This could be ascribed to the physical ruin of the biosorbent (De Lima et al. 2012). Xu et al. (2011c) revealed a weight loss of $12-18 \%$ as a result of using $\mathrm{HCl} 1 \mathrm{M}$ as a desorbent. They attributed this to the corrosion of cellulose/hemicellulose structure. In addition, Biswas (2008) reported the release of $\mathrm{La}$ (III) during desorption when $\mathrm{HCl} 0.4 \mathrm{M}$ was used as an eluent. In view of practical application, these effects are undesirable as they may reduce the stability and thus 
restricting reusability of AWBs. Hence, these factors need to be taken into consideration in exploring for appropriate desorbents. The appropriate desorbents should meet the following criteria: high desorption efficiency, satisfactory reusability of the biosorbent (e.g. negligible reduction in adsorption capacities after many cycles of reuse, marginal weight loss, etc.), and minimal detrimental impacts on the environment.

In some cases, desorption efficiency was found extremely poor e.g. $11.2-13 \%$ (Ismail 2012); 0.7-37.6\% (Kose and Kivanc 2011); 11-13\% (Riahi et al. 2009). It is recommended to use phosphorous bearing AWBs as fertilizers or soil conditioners in acid soils, due to their high contents of nutrients ( $\mathrm{P}, \mathrm{Ca}, \mathrm{Mg}$, etc.) (Loganathan et al. 2014). However, from the recovery of $P$ point of view, with a desire to use recycled $P$ to replace mineral $\mathrm{P}$ in many industries, appropriate AWBs should be easily regenerated and reused. This property needs to be taken into consideration when the selection of potential AWBs is made.

\subsubsection{Factors Influencing Phosphorus Biosorption}

\subsubsection{Effect of $\mathrm{pH}$}

The $\mathrm{pH}$ value of the solution influences the dissociation, $\mathrm{P}$ species abundance, the chemical state of binding sites, and affinity of $\mathrm{P}$ species towards binding sites. The $\mathrm{pH}$ profiles are useful for elucidating sorption mechanisms, optimizing process, and selecting appropriate eluents. Thus, efforts have been directed toward identifying optimum $\mathrm{pH}$ values in various $\mathrm{AWBs}-\mathrm{PO}_{4}{ }^{3-}$ adsorption systems.

Generally, AWBs tend to effectively sequester $\mathrm{PO}_{4}{ }^{3-}$ anions in a specific $\mathrm{pH}$ range, while extremely acidic or alkaline medium is found to suppress the process. Yue et al. (2010) found that $\mathrm{pH}$ range of 4-9 favored the adsorption of $\mathrm{PO}_{4}{ }^{3-}$ onto modified giant reed (MGR), whereas $\mathrm{pH}<4$ or $\mathrm{pH}>9$ was found to be disadvantageous to the process. The authors explained this by dissociation constants of phosphate, dominant phosphate species in the solution, and affinity of phosphate ions towards binding sites. The dissociation constants of $\mathrm{H}_{3} \mathrm{PO}_{4}, \mathrm{H}_{2} \mathrm{PO}_{4}^{-}$and $\mathrm{HPO}_{4}{ }^{2-}$ are 2.12, 7.21 and 12.67, respectively (Biswas 2008). Consequently, the dominant $P$ species can vary, depending on $\mathrm{pH}$ value of the aquatic medium. 
Table 14.2. Comparison of $\mathrm{PO}_{4}{ }^{3-}$ desorption capability of different elution solutions

\begin{tabular}{|c|c|c|c|c|}
\hline Biosorbent & Elution solution & $\begin{array}{l}\text { Desorption efficiency } \\
(\%)\end{array}$ & Remark & References \\
\hline Modified banana stem & $\mathrm{NaOH} 0.1 \mathrm{M}$ & $\begin{array}{l}\text { First cycle } 97.1 \\
\text { Fourth cycle } 90.7\end{array}$ & No weight loss & $\begin{array}{l}\text { Anirudhan et al. } \\
(2006)\end{array}$ \\
\hline Zr(IV)-loaded SOW gel & $\begin{array}{l}\mathrm{NaCl} \\
\mathrm{HCl} \\
\mathrm{NaOH} 0.2 \mathrm{M}\end{array}$ & $\begin{array}{l}\mathrm{NaCl} 0 \\
\mathrm{HCl}<40 \\
\mathrm{NaOH} 95\end{array}$ & $\begin{array}{l}\mathrm{NaOH} \text { exhibited anextremely high } \\
\text { desorption ability without any } \\
\text { remarkable release of loaded } \mathrm{Zr}\end{array}$ & Biswas (2008) \\
\hline La(III)-loaded SOW gel & $\mathrm{HCl} 0.4 \mathrm{M}$ & 85 & Lathanum was leaked & Biswas et al. (2007) \\
\hline Modified coconut shell fibers & $\mathrm{HCl}$ & $\begin{array}{l}\mathrm{C} 1-50 ; \mathrm{C} 2-40 ; \mathrm{C} 3-40 \\
\mathrm{RC} 1-35 ; \mathrm{RC} 2-7\end{array}$ & $\begin{array}{l}\text { Significant loss of } \mathrm{P} \text { adsorption } \\
\text { capacity and remarkable reduction } \\
\text { in } \mathrm{P} \text { removal efficiency }\end{array}$ & $\begin{array}{l}\text { De Lima et al. } \\
(2012)\end{array}$ \\
\hline $\begin{array}{l}\text { Granular date stones (GDS) } \\
\text { Palm surface fibers (PSF) }\end{array}$ & $\mathrm{KCl} 0.01 \mathrm{M}$ & $\begin{array}{l}\text { GDS } 10-11.2 \\
\text { PSF } 12.1-13\end{array}$ & Low desorbability & Ismail (2012) \\
\hline $\begin{array}{l}\text { Quarternized pine bark } \\
\text { residues }\end{array}$ & $\mathrm{NaCl} 0.2 \mathrm{M}$ & 99.8 & $\begin{array}{l}\text { Minor loss }(5.59 \%) \text { in } \mathrm{PO}_{4}{ }^{3-} \\
\text { sorption capacity after } 5 \text { uninter- } \\
\text { rupted sorption-desorption cycles }\end{array}$ & Karachalios (2012) \\
\hline Calcined waste eggshell & $\begin{array}{l}\mathrm{NaOH} 0.5 \mathrm{M} \text { and } \mathrm{NaCl} 0.5 \\
\mathrm{M}\end{array}$ & $\begin{array}{l}\mathrm{NaOH} 37.6 \\
\mathrm{NaCl} 0.7\end{array}$ & - & $\begin{array}{l}\text { Kose and Kivanc } \\
(2011)\end{array}$ \\
\hline Apple peel & $\begin{array}{l}\text { Distilled water at different } \\
\text { pH values }(2-12)\end{array}$ & $\begin{array}{l}\text { Acidic } \mathrm{pH} \text { : minimum } \\
\text { desorption } \\
\text { pH 12: } 90 \text { (10min.) }\end{array}$ & $\begin{array}{l}\mathrm{Zr} \text { was not detached at various } \mathrm{pH} \\
\text { values }\end{array}$ & $\begin{array}{l}\text { Mallampati and } \\
\text { Valiyaveettil (2013) }\end{array}$ \\
\hline $\begin{array}{l}\mathrm{ZnCl}_{2} \text { activated coir pith } \\
\text { carbon }\end{array}$ & $\begin{array}{l}\text { Distilled water at different } \\
\text { pH values }(2-11)\end{array}$ & $\begin{array}{l}\text { pH 2: 30; pH 11:50; } \\
\text { pH 3-11:<10 }\end{array}$ & Low desorbability & $\begin{array}{l}\text { Namasivayam and } \\
\text { Sangeetha }(2004)\end{array}$ \\
\hline $\begin{array}{l}\mathrm{Zr}(\mathrm{IV}) \text { loaded saponified } \\
\text { orange waste }\end{array}$ & $\mathrm{NaOH} 0.2 \mathrm{M}$ & 93 & $\begin{array}{l}\mathrm{Zr} \text { was not leaked during elution } \\
\text { process }\end{array}$ & Ohura et al. (2011) \\
\hline $\begin{array}{l}\text { Iron(III) loaded } \\
\text { carboxylatedpolyacrylamide } \\
\text { grafted sawdust }\end{array}$ & $\begin{array}{l}\text { Different extractants were } \\
\text { tested, including } \mathrm{NaNO}_{3} \text {, } \\
\mathrm{NaCl}, \mathrm{Na}_{2} \mathrm{SO}_{4}, \mathrm{HCl}, \\
\mathrm{HNO}_{3}, \mathrm{NaCl}_{-} \mathrm{HCl}, \mathrm{H}_{2} \mathrm{SO}_{4}, \\
\mathrm{NH}_{4} \mathrm{NO}_{3}-\mathrm{HNO}_{3} \text { and } \mathrm{NaOH}\end{array}$ & $\begin{array}{l}\mathrm{NaOH} 96.8 \\
\mathrm{Na}_{2} \mathrm{SO}_{4} 73.6 \\
\mathrm{NH}_{4} \mathrm{NO}_{3}-\mathrm{HNO}_{3} 50.8 \\
\mathrm{HCl} 36.8 \\
\mathrm{NaCl} 34.5\end{array}$ & $\begin{array}{l}\text { Adsorption capacity reduced by } \\
8.9 \% \text { after } 3 \text { cycles, recovery of } \\
\text { phosphate decreased from } 98.2 \% \text { in } \\
\text { the } 1^{\text {st }} \text { cycle to } 92.8 \% \text { in the } 3^{\text {rd }} \\
\text { cycle, } 3 \% \text { sorbent weight loss after } \\
\text { treatment with } \mathrm{NaOH} 0.1 \mathrm{M}\end{array}$ & $\begin{array}{l}\text { Unnithan et al. } \\
\text { (2002) }\end{array}$ \\
\hline
\end{tabular}


Table 14.2. Continued

\begin{tabular}{|c|c|c|c|c|}
\hline Biosorbent & $\begin{array}{l}\text { Elution } \\
\text { solution }\end{array}$ & $\begin{array}{l}\text { Desorption } \\
\text { efficiency }(\%)\end{array}$ & Remark & References \\
\hline Giant reed & $\begin{array}{l}\mathrm{HCl} 0.1 \mathrm{M} \\
\mathrm{NaCl} 0.1 \mathrm{M} \\
\mathrm{NaOH} 0.1 \mathrm{M}\end{array}$ & $\begin{array}{l}\mathrm{HCl} 100 \\
\mathrm{NaCl} 100 \\
\mathrm{NaOH} 100\end{array}$ & $\begin{array}{l}\text { Weight loss } \\
(1-3 \%)\end{array}$ & $\begin{array}{l}\text { Xu et al. } \\
\text { (2011a) }\end{array}$ \\
\hline $\begin{array}{l}\text { Wheat straw } \\
\text { anion } \\
\text { exchanger }\end{array}$ & $\begin{array}{l}\mathrm{NaCl} 0.1 \mathrm{M} \\
\mathrm{HCl} 0.1 \mathrm{M}\end{array}$ & $\begin{array}{l}\mathrm{NaCl} 86.6-95.4 \\
\mathrm{HCl} 87.4-97.5\end{array}$ & $\begin{array}{l}\text { Marginal } \\
\text { reductions in their } \\
\text { initial adsorption } \\
\text { capacities }\end{array}$ & $\begin{array}{l}\text { Xu et al. } \\
(2010)\end{array}$ \\
\hline $\begin{array}{l}\text { Cotton stalk } \\
\text { (CS) and } \\
\text { wheat stalk } \\
\text { (WS) }\end{array}$ & $\begin{array}{l}\mathrm{NaCl} 0.1 \mathrm{M} \\
\mathrm{HCl} 0.1 \mathrm{M}\end{array}$ & $\begin{array}{l}\text { HCl CS 93.1-98.4; } \\
\text { WS 93.7-98.9 } \\
\text { NaCl CS 92.3-97.1; } \\
\text { WS 95.0-98.2 }\end{array}$ & $\begin{array}{l}5 \% \text { weight loss } \\
\text { with } \mathrm{HCl} 0.1 \mathrm{M}\end{array}$ & $\begin{array}{l}\text { Xu et al. } \\
\text { (2011b) }\end{array}$ \\
\hline $\begin{array}{l}\text { Wheat straw } \\
\text { (WS) }\end{array}$ & $\mathrm{HCl} 1 \mathrm{M}$ & $\begin{array}{l}\text { Medium cost resin: } \\
98-100\end{array}$ & $\begin{array}{l}12-18 \% \text { weight } \\
\text { loss }\end{array}$ & $\begin{array}{l}\text { Xu et al. } \\
(2011 \mathrm{c})\end{array}$ \\
\hline $\begin{array}{l}\text { Sugarcane } \\
\text { bagasse }\end{array}$ & $\mathrm{NaOH} 0.05 \mathrm{M}$ & 95.6 & & $\begin{array}{l}\text { Zhang et al. } \\
(2012)\end{array}$ \\
\hline
\end{tabular}

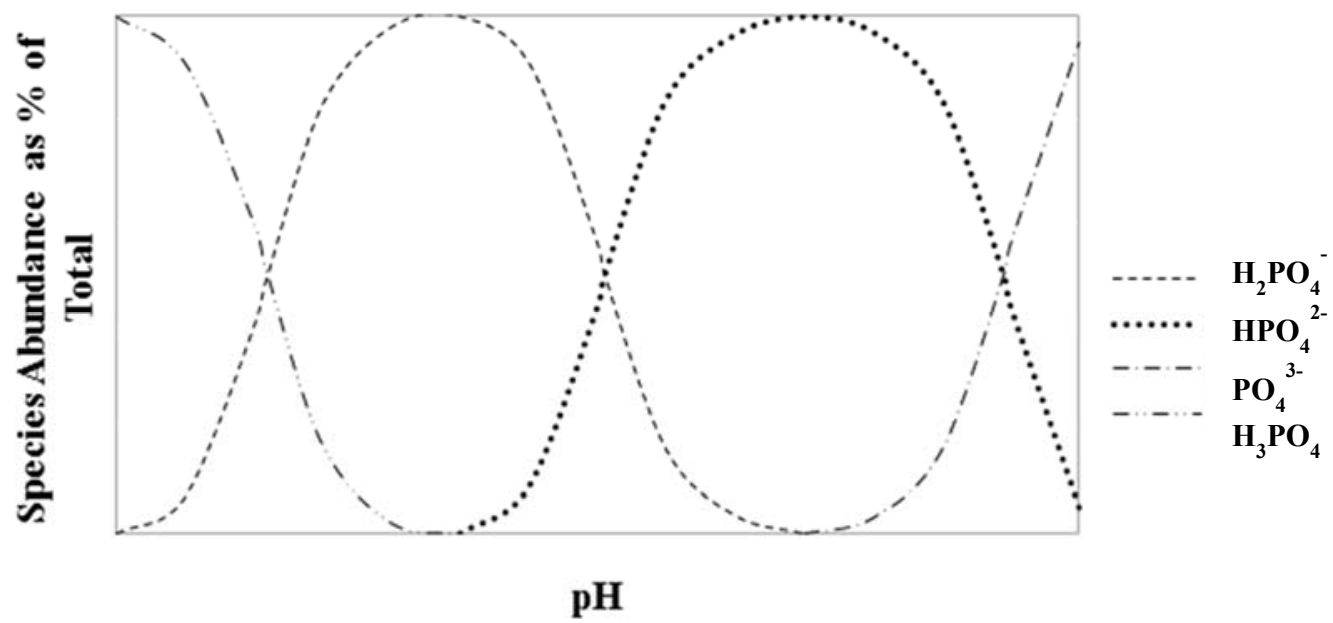

Figure 14.3. Orthophosphate species as a proportion of the total orthophosphate concentration (Hanrahan et al. 2005)

As can be seen from Figure 14.3, in the $\mathrm{pH}$ range of 4-9, $\mathrm{H}_{2} \mathrm{PO}_{4}^{-}$and $\mathrm{HPO}_{4}{ }^{2-}$ species were dominant. Due to their strong affinity toward binding sites, the sorption of $\mathrm{P}$ was enhanced. In contrast, at $\mathrm{pH}<4$, the $\mathrm{H}_{3} \mathrm{PO}_{4}$ and $\mathrm{HPO}_{4}{ }^{2-}$ species were most common. Their inferior affinities toward binding sites led to the poor removal of $\mathrm{P}$. In the same way, at $\mathrm{pH}>9, \mathrm{HPO}_{4}{ }^{2-}$ and $\mathrm{PO}_{4}{ }^{3-}$ species were prevalent. The weak affinity of these species for active site combined with strong competition between $\mathrm{OH}^{-}$ions and $\mathrm{PO}_{4}{ }^{3-}$ ions for adsorption sites hampered the process. Similarly, the effective $\mathrm{pH}$ range was found to be 5-7 for modified banana stem (Anirudhan et al. 2006); 7-10 for metal loaded orange waste gel (Biswas 2008); 3.5-6.0 for quaternized pine bark residues (Karachalios 2012); 3-10 for $\mathrm{ZnCl}_{2}$ activated coir pith carbon (Namasivayam and Sangeetha 2004); 3-11 for calcined waste eggshell and modified 
sugarcane bagasse (Xu et al. 2011a; Zhang et al. 2012); 4-9 for modified giant reed (Yue et al. 2010), etc. This trend more or less agrees with the findings reported by Riahi et al. (2009) and Ismail (2012). They both found that an increase in the $\mathrm{pH}$ value led to a decrease in the $\mathrm{P}$ uptake. The authors explained this phenomenon by stronger repulsion force in the alkaline medium. The optimum $\mathrm{pH}$ values were found to be low (e.g. 2, 3) by Krishnan and Haridas (2008); Jeon and Yeom (2009); Mallampati and Valiyaveetttil (2013). On the other hand, high optimum pH values (e.g. 7.5, 10) were reported by Biswas (2008); Benyoucef and Amrani (2011); Jyothi et al. (2012). The former was explained by the dominance of $\mathrm{H}_{2} \mathrm{PO}_{4}{ }^{-}$species and their affinity toward binding sites in acidic medium (Mallampati and Valiyaveetttil 2013). In contrast, the latter was attributed to the possible existence of natural compounds and metal ions (e.g. $\mathrm{Ca}, \mathrm{Mg}, \mathrm{Fe}, \mathrm{Al}, \mathrm{Cu}, \mathrm{Zn}$ ) inside these $\mathrm{AWBs}$, which had strong affinity toward $\mathrm{HPO}_{4}{ }^{2-}$ in alkaline medium (Jyothi et al. 2012). It is worth pointing out that, in some studies, a wide $\mathrm{pH}$ range was found to have a marginal effect on the sorption of $\mathrm{PO}_{4}{ }^{3-}$, e.g. 4-10 for crab shells (Jeon and Yeom 2009); 5.0-10.5 for oyster shell powder (Namasivayam et al. 2005); 2-7.5 for scallop shells (Yeom and Jung 2009). Especially, De Lima et al. (2012) claimed that $\mathrm{pH}$ could hardly affect the sorption of $\mathrm{PO}_{4}{ }^{3-}$ onto coconut fiber. It seems that many AWBs are highly effective in a wide $\mathrm{pH}$ range. This property represents an appreciable advantage of AWBs over conventional adsorbents for $\mathrm{PO}_{4}{ }^{3-}$ removal.

\subsubsection{Effect of Temperature}

Normally, the adsorptive removal of $\mathrm{PO}_{4}{ }^{3-}$ by AWBs is temperature sensitive. Some adsorption processes are endothermic, whilst others have exothermic nature. Mezenner and Bensmaili (2009) found that the retention of $\mathrm{PO}_{4}{ }^{3-}$ by iron hydroxide eggshell was enhanced with a rise in the temperature from 20 to $45{ }^{\circ} \mathrm{C}$. From the positive $\Delta \mathrm{H}^{\circ}(81.84 \mathrm{~kJ} / \mathrm{mol})$, they concluded that the adsorption was endothermic. It was assumed that, higher temperature led to the better solubility of iron hydroxide eggshell compound, and thus producing more iron and calcium hydrolysis complexes. Consequently, the phosphate precipitation was enhanced. Similar observations were noticed by Boujelben et al. (2008), Yeom and Yung (2009), Kumar et al. (2010), Benyoucef and Amrani (2011), Chen et al. (2012), and Peng et al. (2012). Benyoucef and Amrani (2011) explained this phenomenon by the enlargement of pore sizes, whereas Kumar et al. (2010) ascribed this to the better dissolution of $\mathrm{PO}_{4}{ }^{3-}$ ions and higher rate of intra-particle diffusion at higher temperature. On the contrary, Yue et al. (2010) explored that the $\mathrm{P}$ uptake by modified giant reed declined from 19.89 to $17.79 \mathrm{mg} / \mathrm{g}$ as the temperature increased from 20 to $60^{\circ} \mathrm{C}$, indicating the exothermic nature of the adsorption process. From negative values of $\Delta G^{\circ}$ and $\Delta H^{\circ}$, Karachalios (2012) concluded that the adsorption of $\mathrm{PO}_{4}{ }^{3-}$ by quaternized pine bark residues was exothermic. These results were in harmony with those reported by Kose and Kivanc (2011) and $\mathrm{Xu}$ et al. (2009). They explained that higher temperature resulted in stronger leakage of $\mathrm{PO}_{4}{ }^{3-}$ ions from AWBs surface into the solution (Xu et al. 2009). Particularly, the change in the temperature from 15 to $45{ }^{\circ} \mathrm{C}$ could hardly affect the sorption of $\mathrm{PO}_{4}{ }^{3-}$ onto crab shell (Jeon and Yeom 2009). 


\subsubsection{Effect of Initial Phosphorus Concentration}

Typically, the uptake capacity of $\mathrm{PO}_{4}{ }^{3-}$ increased, whilst the $\mathrm{PO}_{4}{ }^{3-}$ removal efficiency decreased with a rise in the initial concentration of $\mathrm{PO}_{4}{ }^{3-}$ ions. On the one hand, Mezenner and Bensmaili (2009) claimed that the extent of $\mathrm{PO}_{4}{ }^{3-}$ removal by iron hydroxide eggshell waste decreased from 95 to $64 \%$ with increasing initial concentration of phosphate from 2.8 to $110 \mathrm{mg} / \mathrm{L}$. Similar tendency has been reported for sugarcane bagasse by Zhang et al. (2012). The authors explained this by higher ratio of $\mathrm{PO}_{4}^{3-}$ moles to the active binding sites at higher $\mathrm{PO}_{4}{ }^{3-}$ initial concentrations. For a specific dose of AWBs, the amount of binding sites is unchanged. Therefore, an increase in initial concentration of $\mathrm{PO}_{4}{ }^{3-}$ led to the decrease in its percentage removal accordingly. On the other hand, Riahi et al. (2009) reported that the $\mathrm{PO}_{4}{ }^{3-}$ adsorption capacity of date palm fibers increased from 1.45 to $5.85 \mathrm{mg} / \mathrm{g}$ as the initial phosphate concentration increased from 10 to $110 \mathrm{mg} / \mathrm{L}$. These results were in consistent with those reported by Anirudhan et al. (2006); Mezenner and Bensmaili (2009); Xu et al. (2009); Kumar et al. (2010); Yue et al. (2010) and Zhang et al. (2012). Both Kumar et al. (2010) and Yue et al. (2010) attributed this to the stronger driving force to convey $\mathrm{PO}_{4}{ }^{3-}$ ions from solution to the surface of $\mathrm{AWBs}$ at higher $\mathrm{PO}_{4}{ }^{3-}$ initial concentrations. Mezenner and Bensmaili (2009) and Riahi et al. (2009) ascribed this to increasing interaction between binding sties and $\mathrm{PO}_{4}{ }^{3-}$ ions, which resulted from the increase of $\mathrm{PO}_{4}{ }^{3-}$ ions provided by higher $\mathrm{PO}_{4}{ }^{3-}$ initial concentrations.

\subsubsection{Effect of AWBs Dosage}

The general trend is that $\mathrm{PO}_{4}{ }^{3-}$ removal efficiency increases with a rise in the AWBs dose to a certain level then remains constant or reduces slightly with further increase in the AWBs dose. The better $\mathrm{PO}_{4}{ }^{3-}$ removal efficiency at higher AWBs dose was explained by more binding sites for $\mathrm{PO}_{4}{ }^{3-}$ adsorption and larger surface area available at higher dose of AWBs (Xu et al. 2009; Kose and Kivanc 2011; Zhang et al. 2012). The reduction in the $\mathrm{PO}_{4}{ }^{3-}$ removal efficiency when the AWBs dose exceeded the optimum dose could be attributed to the resistance to mass transfer, particle aggregates and repulsive forces between binding sites at higher dose (Mezenner and Bensmaili 2009; Riahi et al. 2009; Ismail 2012). On the contrary, an increase in the dose of AWBs results in a reduction in P uptake capability. Karachalios (2012) found that the $\mathrm{PO}_{4}{ }^{3-}$ uptake by modified pine bark residues decreased from 55 to $25 \mathrm{mg} / \mathrm{g}$ as the dose increased from 0.5 to $5 \mathrm{~g} / \mathrm{L}$. These results are in harmony with those reported by Yue et al. (2010) and Zhang et al. (2012). This could be ascribed to the lower $\mathrm{PO}_{4}{ }^{3-}$ concentration gradient between solution and sorbent surface (Zhang et al. 2012). Conversely, Riahi et al. (2009) explored that the $\mathrm{PO}_{4}{ }^{3-}$ uptake increased from 3.75 to $4.69 \mathrm{mg} / \mathrm{g}$ as date palm fiber dose increased from 2 to $6 \mathrm{~g} / \mathrm{L}$. However, further increase in biosorbent dose suppressed the sorption process. This can be explained by poor interaction between $\mathrm{PO}_{4}{ }^{3-}$ ions and the biosorbent as a result of the roll up of fibers at excessive doses. In view of practical application, for the same removal efficiency, the lower the AWBs dose, the better the efficacy of AWBs is. For the 
referring purpose, $\mathrm{PO}_{4}{ }^{3-}$ removal efficiency and the corresponding dose of AWBs in various adsorption systems were introduced as follows: $79.8 \%$ for $1 \mathrm{~g} / \mathrm{L}$ of $\mathrm{MSBG}$ (Zhang et al. 2012); $92.5 \%$ for $2 \mathrm{~g} / \mathrm{L}$ of modified wheat residue (Xu et al. 2009); $85-87 \%$ for $5 \mathrm{~g} / \mathrm{L}$ of date palm wastes (Ismail 2012); $99.6 \%$ for $10 \mathrm{~g} / \mathrm{L}$ of calcined waste eggshell (Kose and Kivanc 2011); and 98\% for $16 \mathrm{~g} / \mathrm{L}$ of modified giant reed (Yue et al. 2010).

\subsubsection{Effect of Interfering Anions}

Examining the effect of co-existing ions on the adsorption of $\mathrm{PO}_{4}{ }^{3-}$ by $\mathrm{AWBs}$ is necessary to enhance the practical application of these biosorbents. Namasivayam and Sangeetha (2004) reported that $\mathrm{Cl}^{-}, \mathrm{NO}_{3}{ }^{-}, \mathrm{MoO}_{4}{ }^{2-}, \mathrm{VO}_{3}{ }^{-}$scarcely affected the $\mathrm{PO}_{4}{ }^{3-}$ removal by $\mathrm{ZnCl}_{2}$ activated coir pith carbon. Equally, Biswas et al. (2007) revealed that the adsorption of $\mathrm{PO}_{4}{ }^{3-}$ onto $\mathrm{La}(\mathrm{III})$ loaded $\mathrm{SOW}$ gel was not substantially influenced by the addition of $\mathrm{Cl}^{-}, \mathrm{CO}_{3}{ }^{2-}, \mathrm{SO}_{4}{ }^{2-}$. In a later study, Biswas (2008) revealed that $\mathrm{Cl}^{-}(0.56 \mathrm{mM}), \mathrm{CO}_{3}{ }^{2-}(0.33 \mathrm{mM}), \mathrm{SO}_{4}{ }^{2-}(0.42 \mathrm{mM})$ could hardly affect the sorption of $\mathrm{PO}_{4}{ }^{3-}(0.20 \mathrm{mM})$. Kose and Kivanc (2011) claimed that the addition of $\mathrm{SO}_{4}{ }^{2-}, \mathrm{NO}_{3}{ }^{-}$and $\mathrm{NH}_{4}{ }^{+}$with the concentrations ranging from 10 to $50 \mathrm{mg} / \mathrm{L}$ had minor influences on the retention of $\mathrm{PO}_{4}{ }^{3-}$ by calcined waste eggshell. Jyothi et al. (2012) discovered that such foreign anions as $\mathrm{Cl}^{-}, \mathrm{SO}_{4}{ }^{2-}, \mathrm{NO}_{3}{ }^{-}, \mathrm{F}^{-}$and $\mathrm{CO}_{3}{ }^{2-}$ with the same concentration had minimum interference on the sorption of $\mathrm{PO}_{4}{ }^{3-}$ by thermally activated barks/stems and their ashes of Ficus religiosa,Cassia auriculata, Punica granatum and Calotropis gigantean. The adsorption of $\mathrm{PO}_{4}{ }^{3-}$ by $\mathrm{AWBs}$ was not affected by the presence of co-anions, implying the potential for employing these AWBs to the real wastewater. On the other hand, Namasivayam and Sangeetha (2004) explored that the presence of $\mathrm{ClO}_{4}^{-}, \mathrm{SeO}_{3}{ }^{2-}$ and $\mathrm{SO}_{4}{ }^{2-}$ with the same concentrations as $\mathrm{PO}_{4}{ }^{3-}$ hampered the removal of $\mathrm{PO}_{4}{ }^{3-}$ ions. Likewise, Karachalios (2012) claimed that $\mathrm{SO}_{4}{ }^{2-}$ was superior to $\mathrm{NO}_{3}{ }^{-}$in competing with $\mathrm{PO}_{4}{ }^{3-}$ for binding sites. The higher $\mathrm{Cl}^{-}$concentrations resulted in the lower $\mathrm{PO}_{4}{ }^{3-}$ uptake. It is interesting to note that presence of divalent cations (i.g. $\mathrm{Ca}^{2+}, \mathrm{Mg}^{2+}, \mathrm{Cu}^{2+}, \mathrm{Zn}^{2+}, \mathrm{Fe}^{2+}$ and $\mathrm{Ni}^{2+}$ ) with the concentration 10 times greater than that of $\mathrm{PO}_{4}{ }^{3-}$, boosted the $\mathrm{PO}_{4}{ }^{3-}$ extraction by thermally activated barks/ stems and their ashes of Ficus religiosa, Cassia auriculata, Punica granatum and Calotropis gigantean (Jyothi et al. 2012). The positive effect of divalent cations on the adsorption process suggests a way further to improve the $\mathrm{PO}_{4}{ }^{3-}$ adsorption capacity of these biosorbents.

\subsubsection{Effect of Contact Time}

The contact time is an indicator of the speed of the adsorption process. Therefore, it is a critical factor in evaluating the efficacy of AWBs (Eljamal et al. 2013). In many cases, the adsorption was found to be rapid, reaching the equilibrium in approximately $1 \mathrm{~h}$. The equilibrium time was found to be $20 \mathrm{~min}$. for quaternized wood residues (Karachalios 2012); 25 min. for modified giant reed (Yue et al. 2010); $40 \mathrm{~min}$. for modified sawdust (Benyoucef and Amrani 2011); and $60 \mathrm{~min}$. for natural date palm wastes (Ismail 2012) and sugarcane bagasse (Zhang et al. 2011). In 
contrast, the longer contact time was necessary for the equilibrium to be reached by other AWBs. It was shown to be $15 \mathrm{~h}$ for $\mathrm{La}(\mathrm{III}), \mathrm{Ce}(\mathrm{III})$ and $\mathrm{Zr}$ (IV) loaded SOW gels (Biswas 2008); $12 \mathrm{~h}$ for iron impregnated coir pith (Krishnan and Haridas 2008); and $6 \mathrm{~h}$ for $\mathrm{Zr}(\mathrm{IV})$ loaded apple peels (Mallampati and Valiyaveettil 2013). The short contact time means that AWBs do not have to be kept in reactors for a long time, and thus the space can be saved. This can be considered as an advantageous property of potential AWBs, from a practical application point of view.

\subsubsection{Effect of Particle Sizes of AWBs}

Chen et al. (2012) found that $\mathrm{PO}_{4}{ }^{3-}$ uptake capacity increased with a decrease in oyster shell diameter from 590 to $180 \mu \mathrm{m}$. Similarly, Yeom and Jung (2009) revealed that $100 \mathrm{mg} \mathrm{PO}_{4}^{3-} / \mathrm{L}$ could be removed entirely by $1 \mathrm{~g}$ of scallop shells of $0.045 \mathrm{~mm}$ diameter in $3 \mathrm{~h}$, whereas it was scarcely eliminated by that of $3 \mathrm{~mm}$ in $80 \mathrm{~h}$. In the same way, Jeon and Yeom (2009) found that crab shells particles $<1 \mathrm{~mm}$ in diameter showed a removal percentage $>85 \%$, whereas particles $3.35 \mathrm{~mm}$ could remove only $50 \%$. These proved that smaller size of AWBs had an advantage when used for the adsorption of P. However, for prevention of a clogging problem in a packed-bed reactor, the optimum particles sizes need to be identified. 
Table 14.3. Phosphate adsorption capacity and processing parameters of diverse phosphate - AWBs adsorption systems

\begin{tabular}{|c|c|c|c|c|c|c|c|c|}
\hline Biosorbent & $\begin{array}{l}\text { Ads. cap. } \\
\text { (mg PO }_{4}{ }^{3-} / \mathrm{g} \\
\text { AWBs) }\end{array}$ & $\mathbf{p H}$ & $\begin{array}{l}\text { Tem. } \\
\left({ }^{\circ} \mathbf{K}\right)\end{array}$ & $\begin{array}{l}\text { Initial P } \\
\text { con. }(\mathrm{mg} / \mathrm{L})\end{array}$ & $\begin{array}{l}\text { Bios. } \\
\text { dose } \\
(\mathrm{g} / \mathrm{L}) \\
\end{array}$ & $\begin{array}{l}\text { Cont. } \\
\text { time } \\
\text { (min.) }\end{array}$ & $\begin{array}{l}\text { Shaking } \\
\text { speed } \\
\text { (rpm) }\end{array}$ & References \\
\hline \multicolumn{9}{|l|}{ Natural AWBs } \\
\hline Giant reed & $\begin{array}{l}0.836 \\
\text { column }\end{array}$ & $5-10(\mathrm{opt})$ & - & - & - & - & - & Xu et al. (2011a) \\
\hline Sugarcane bagasse & 1.10 & $4-11$ (opt) & 293 & $50 \mathrm{PO}_{4}{ }^{3-}$ & 1 & 180 & 120 & Zhang et al. (2012) \\
\hline Coir pith & 4.35 & 3 & & $50 \mathrm{PO}_{4}^{3-}$ & 2 & 960 & & Krishnan and Haridas (2008) \\
\hline Date palm fibers & 13.33 & 6.8 & $291 \pm 2$ & $50 \mathrm{PO}_{4}^{3-}$ & 6 & 120 & 200 & Riahi et al. (2009) \\
\hline Scallop shells & 23.00 & - & - & - & - & - & - & Yeom and Jung (2009) \\
\hline Palm surface fibers & 26.05 & $7-7.5$ & 298 & $\begin{array}{l}5,10,25,50 \\
\mathrm{P}\end{array}$ & 5 & 120 & 200 & Ismail (2012) \\
\hline Granular date stones & 26.66 & $7-7.5$ & 298 & $\begin{array}{l}5,10,25,50 \\
\mathrm{P}\end{array}$ & 5 & 120 & 200 & Ismail (2012) \\
\hline $\begin{array}{l}\text { Crab shells } \\
\text { Modified AWBs }\end{array}$ & 108.9 & $2.0(\mathrm{opt})$ & - & - & - & - & 250 & Jeon and Yeom (2009) \\
\hline Coir pith & 5.10 & $3-10$ & 308 & $10-40 \mathrm{PO}_{4}^{3-}$ & 6 & - & 200 & $\begin{array}{l}\text { Namasivayam and Sangeetha } \\
\text { (2004) }\end{array}$ \\
\hline Juniper fibre & 7.08 & - & 298 & $10 \mathrm{P}$ & $2-20$ & 1440 & 150 & Han et al. (2005) \\
\hline Coir pith & 7.74 & $6(\mathrm{opt})$ & 308 & $40 \mathrm{P}$ & 4 & 180 & 150 & Kumar et al. (2010) \\
\hline Bark & 12.65 & - & $298 \pm 1$ & $0.1 \div 500 \mathrm{P}$ & 2.5 & 1440 & 7 & Tshabalala et al. (2004) \\
\hline Eggshell & 14.49 & - & $\begin{array}{l}293-31 \\
8\end{array}$ & $\begin{array}{l}2.8-110 \\
\mathrm{PO}_{4}^{3-}\end{array}$ & $2.5-20$ & - & - & $\begin{array}{l}\text { Mezenner and Bensmaili } \\
\text { (2009) }\end{array}$ \\
\hline Biomass char & 15.11 & - & $298 \pm 0.5$ & $30 \mathrm{PO}_{4}^{3-}$ & 1 & 300 & 100 & Peng et al. (2012) \\
\hline $\begin{array}{l}\text { Wood particles } \\
\text { (modified by } 2 \\
\text { methods) }\end{array}$ & $2.05 \& 17.38$ & - & 298 & $100 \mathrm{PO}_{4}^{3-}$ & 4 & 1440 & 150 & Eberhardt and Min (2008) \\
\hline Soybean hulls & 19.84 & 7 & 298 & $620 \mathrm{P}$ & 10 & 1440 & 300 & Marshall and Wartelle (2004) \\
\hline Apple peel & 20.35 & 2 (opt) & 303 & $5-200 \mathrm{PO}_{4}^{3-}$ & 10 & 360 & 200 & $\begin{array}{l}\text { Mallampati and Valiyaveettil } \\
\text { (2013) }\end{array}$ \\
\hline
\end{tabular}

Note: Ads. cap. $=$ Adsorption capacity; Tem. $=$ Temperature; Con. $=$ concentration; Bios. $=$ Biosorbent; Cont. $=$ Contact 
Table 14.3. Continued

\begin{tabular}{|c|c|c|c|c|c|c|c|c|}
\hline Biosorbent & $\begin{array}{l}\text { Ads. cap. } \\
\text { (mg PO }_{4}{ }^{3-} \\
\text { /g AWBs) }\end{array}$ & pH & $\begin{array}{l}\text { Tem. } \\
\left({ }^{\circ} \mathbf{K}\right)\end{array}$ & $\begin{array}{l}\text { Initial P } \\
\text { con. } \\
(\mathbf{m g} / \mathrm{L})\end{array}$ & $\begin{array}{l}\text { Bios. } \\
\text { dose } \\
(\mathrm{g} / \mathrm{L})\end{array}$ & $\begin{array}{l}\text { Cont. } \\
\text { time } \\
(\mathrm{min} .)\end{array}$ & $\begin{array}{l}\text { Shaking } \\
\text { speed } \\
\text { (rpm) }\end{array}$ & References \\
\hline \multicolumn{9}{|l|}{ Modified AWBs } \\
\hline Sugarcane bagasse & 21.30 & $4-11$ & 293 & $50 \mathrm{PO}_{4}^{3-}$ & 1 & 180 & 120 & Zhang et al. (2012) \\
\hline Coir pith & 22.05 & 3 & & $50 \mathrm{PO}_{4}^{3-}$ & 2 & 960 & & Krishnan and Haridas (2008) \\
\hline Eggshell & 23.02 & $2-10$ & 298 & $100 \mathrm{PO}_{4}^{3-}$ & 2 (opt) & 60 & 140 & Kose and Kivanc (2011) \\
\hline Wood & 26.03 & - & $298 \pm 1$ & $0.1-200 \mathrm{P}$ & 1.67 & 1200 & 7 & Karthikeyan et al. (2004) \\
\hline Juniper bark fibre & 33.35 & $6(\mathrm{opt})$ & 298 & $1-450 \mathrm{P}$ & 1 & 720 & & Shin et al. (2005) \\
\hline $\begin{array}{l}\text { La(III) loaded orange waste } \\
\text { gel }\end{array}$ & 42.72 & 7.5 (opt) & 303 & $20 \mathrm{P}$ & 1.7 & 1440 & 140 & Biswas et al. (2007) \\
\hline $\begin{array}{l}\text { Ce(III) loaded orange waste } \\
\text { gel }\end{array}$ & 42.72 & 7.5 (opt) & 303 & $20 \mathrm{P}$ & 1.7 & 1440 & 140 & Biswas et al. (2007) \\
\hline $\begin{array}{l}\text { Fe(III) loaded orange waste } \\
\text { gel }\end{array}$ & 42.72 & 3.0 (opt) & 303 & $20 \mathrm{P}$ & 1.7 & 1440 & 140 & Biswas et al. (2007) \\
\hline Bark & 44.65 & - & $298 \pm 1$ & $0.1-200 \mathrm{P}$ & 1.67 & 1200 & 7 & Karthikeyan et al. (2004) \\
\hline Wheat residue & 45.70 & - & - & $50-500 \mathrm{PO}_{4}^{3-}$ & - & - & - & Xu et al. (2010) \\
\hline Giant reed & $\begin{array}{l}54.67 \\
\text { column }\end{array}$ & $\begin{array}{l}5-10 \\
\text { (opt) }\end{array}$ & - & - & - & - & - & Xu et al. (2011a) \\
\hline Giant reed & 60.95 & $\begin{array}{l}4-9 \\
\text { (opt) }\end{array}$ & 293 & $10-200 \mathrm{P}$ & 1 & 60 & 200 & Yue et al. (2010) \\
\hline Corn stover & 62.70 & 7 & 298 & & 10 & 1440 & 300 & Wartelle and Marshall (2006) \\
\hline $\begin{array}{l}\text { Skin split waste } \\
\text { (loaded with } 2 \text { types of } \\
\text { metals) }\end{array}$ & $\begin{array}{l}21.65 \& \\
72.00\end{array}$ & 7 & 303 & $\begin{array}{l}47.5-285 \\
\mathrm{PO}_{4}^{3-}\end{array}$ & 1 & 1440 & - & Huang et al. (2009) \\
\hline Banana stem & 72.46 & $2-10$ & 303 & $10-300 \mathrm{PO}_{4}{ }^{3-}$ & 2 & & 200 & Anirudhan et al. (2006) \\
\hline Sawdust of Aleppo pine & 116.25 & $7.5(\mathrm{opt})$ & 298 & $300 \mathrm{PO}_{4}^{3-}$ & 2 & 40 & 120 & Benyoucef and Amrani (2011) \\
\hline Pine bark residues & 205.63 & $\begin{array}{l}3.5-6 \\
\text { (opt) }\end{array}$ & 293 & $200 \mathrm{P}$ & $\begin{array}{l}1.25 \\
\text { (opt) }\end{array}$ & 1440 & 200 & Karachalios (2012) \\
\hline
\end{tabular}




\subsection{Applications}

\subsubsection{Phosphorus Adsorption Performance by Unmodified AWBs}

Unmodified AWBs have received far less attention for being used as adsorbents for the removal of $\mathrm{PO}_{4}{ }^{3-}$ than their modified counterparts. Up to date, only a few reports exist on the use of raw AWBs for eliminating $\mathrm{PO}_{4}{ }^{3-}$ e.g. Krishnan and Haridas (2008), Jeon and Yeom (2009), Riahi et al. (2009), Yeom and Yung (2009), $\mathrm{Xu}$ et al. (2011a), Ismail (2012), and Zhang et al. (2012). Table 14.3 introduces some natural $\mathrm{AWBs}$ and their reported adsorption capacities for $\mathrm{PO}_{4}^{3-}$. For comparison purpose, the levels of $\mathrm{PO}_{4}{ }^{3-}$ retention by typical conventional adsorbents are shown in Table 14.4.

Table 14.4. Maximum adsorption capacity of various conventional adsorbents

\begin{tabular}{|c|c|c|}
\hline Adsorbent & $\begin{array}{l}\mathrm{q}_{\max } \\
\left(\mathrm{mg} \mathrm{PO}_{4}{ }^{3-} / \mathrm{g}\right)\end{array}$ & References \\
\hline \multicolumn{3}{|l|}{ Natural adsorbents } \\
\hline Zeolite & 0.92 & Jiang et al. (2013) \\
\hline $\mathrm{Pb}-\mathrm{Zn}$ tailings & 1.07 & Wang et al. (2013) \\
\hline Pyrrhotite & 1.15 & Li et al. (2013) \\
\hline Granular boehmite & 8.40 & Ogata et al. (2012) \\
\hline Fe-Mn binary oxide & 22.99 & Zhang et al. (2009) \\
\hline $\begin{array}{l}\text { Composite metal oxides synthesized } \\
\text { from Mn ore tailings }\end{array}$ & 26.30 & Liu et al. (2012) \\
\hline Pumice & 36.40 & Karimaian et al. (2013) \\
\hline Hydrous zirconium oxide & $\begin{array}{l}61.00-66.00 \\
(298-338 \mathrm{~K})\end{array}$ & Rodrigues et al. (2012) \\
\hline Fe-Zr binary oxide & $76.31(\mathrm{pH} 8.5)$ & Ren et al. (2012) \\
\hline Tantalum hydroxide & $\begin{array}{l}78.50-97.00 \\
(298-338 \mathrm{~K})\end{array}$ & Yu et al. (2012) \\
\hline AMD (Acid mine drainage sludge) & 98.00 & Bhojappa (2009) \\
\hline $\mathrm{Fe}-\mathrm{Zr}$ binary oxide & $102.35(\mathrm{pH} \mathrm{5.5)}$ & Ren et al. (2012) \\
\hline Goethite & 144.00 & Peleka and Deliyanni (2009) \\
\hline Titanium & 151.02 & Choi et al. (2011) \\
\hline \multicolumn{3}{|l|}{ Modified adsorbents } \\
\hline Naturally iron oxide coated sand & 0.88 & Boujelben et al. (2008) \\
\hline Synthetic iron oxide coated & 1.50 & Boujelben et al. (2008) \\
\hline Iron oxide coated crushed brick & 1.80 & Boujelben et al. (2008) \\
\hline Sponge iron & 3.37 & Jiang et al. (2013) \\
\hline Vesuvianite doped with La(III) & 4.05 & Li et al. (2009) \\
\hline $\begin{array}{l}\text { Activated carbon fiber loaded with } \\
\text { La(III) oxide }\end{array}$ & 5.85 & Zhang et al. (2011) \\
\hline Zeolite modified with La/Al & 7.44 & Meng et al. (2013) \\
\hline $\begin{array}{l}\text { Activated carbon fibre doped with } \\
\text { La(III) }\end{array}$ & $\begin{array}{l}6.34-7.92(\mathrm{NaCl} \\
0.001 \text { to } 0.1 \mathrm{M})\end{array}$ & Liu et al. (2011) \\
\hline
\end{tabular}


Table 14.4. Continued

\begin{tabular}{|c|c|c|}
\hline Adsorbent & $\begin{array}{l}\mathrm{q}_{\max } \\
\left(\mathrm{mg} \mathrm{PO}{ }_{4}{ }^{3-} / \mathrm{g}\right)\end{array}$ & References \\
\hline \multicolumn{3}{|l|}{ Modified adsorbents } \\
\hline Activated carbon doped with $\mathrm{Fe}(\mathrm{III})$ & 8.13 & Wang et al. (2012) \\
\hline Activated alumina & 9.90 & Li et al. (2009) \\
\hline $\begin{array}{l}\text { Montmorillonite pillared with } \mathrm{Al} / \\
\mathrm{La}-\mathrm{Al}\end{array}$ & $10.31 / 13.02$ & Tian et al. (2009) \\
\hline $\begin{array}{l}\text { Bentonite modified with } \mathrm{Al} / \mathrm{Fe} / \mathrm{Fe}- \\
\mathrm{Al}\end{array}$ & $12.7 / 11.20 / 10.50$ & Yan et al. (2010) \\
\hline Activated carbon doped with $\mathrm{Fe}(\mathrm{II})$ & 14.12 & Wang et al. (2012) \\
\hline Zeolite modified with lanthanide & 24.60 & Ning et al. (2008) \\
\hline Silica sulphate & 46.32 & Jutidamrongphan et al. (2012) \\
\hline Pumice modified with $\mathrm{MgCl}_{2}$ & 54.27 & Karimaian et al. (2013) \\
\hline Hydrotalcite coated with sulphate & 68.09 & Choi et al. (2012) \\
\hline Fe(III)-AM-PGMACell & 70.11 & Anirudhan and Senan (2011) \\
\hline $\begin{array}{l}\text { Activated alumina coated with } \\
\text { sulphate }\end{array}$ & 152.21 & Choi et al. (2012) \\
\hline $\begin{array}{l}\text { Zeolite coated with sulphate } \\
\text { Commerical adsorbents }\end{array}$ & 341.66 & Choi et al. (2012) \\
\hline Zr-MCM 41 & 3.36 & Jutidamrongphan et al. (2012) \\
\hline Whatman QA-52 & 14.26 & Marshall and Wartelle (2004) \\
\hline Zirconium ferrite & 27.73 & Jutidamrongphan et al. (2012) \\
\hline Duolite A-7 & 31.74 & Anirudhan et al. (2006) \\
\hline Amberlite IRA-400 & 32.24 & Marshall and Wartelle (2004) \\
\hline Aluminium oxide & 34.57 & Peleka and Deliyanni (2009) \\
\hline Zirconium ferrite & 39.84 & Biswas (2008) \\
\hline Dowex & 40.23 & Anirudhan and Senan (2011) \\
\hline Hydrotalcite & 60.00 & Peleka and Deliyanni (2009) \\
\hline Zirconium loaded MUROMAC & 131.77 & Biswas (2008) \\
\hline
\end{tabular}

Among existing raw AWBs, crab shell displayed the highest $\mathrm{PO}_{4}{ }^{3-}$ adsorption capacity (108.9 mg/g) (Jeon and Yeom 2009). This value is higher than those obtained with the majority of the commercial adsorbents $(3.36-60 \mathrm{mg} / \mathrm{g})$. This was assumed that not only calcium carbonate but also proteins and cellulose-like backbone of the crab shells played significant roles in the $\mathrm{PO}_{4}{ }^{3-}$ retention. The extremely good adsorption capacity places crab shell among the best AWBs currently available for $\mathrm{PO}_{4}{ }^{3-}$ removal, in term of the adsorption capacity. In contrast, other unmodified AWBs displayed the adsorption capacity in the range of 1.10-26.66 $\mathrm{mg} / \mathrm{g}$. These values are significantly lower when compared with many well-known commercial adsorbents (31.74-131.77 $\mathrm{mg} / \mathrm{g})$. Obviously, with very few exceptions, the removal of $\mathrm{PO}_{4}{ }^{3-}$ by unmodified AWBs was not efficient enough for practical implications. This can be explained by the fact that as the lignocellulosic materials, unmodified AWBs contain a large amount of negatively charged functional groups 
$(-\mathrm{OH},-\mathrm{COOH})$ on their surface. Consequently, raw AWBs are supposed to be less effective in decontaminating anionic contaminants than cationic ones (Mallampati and Valiyaveetttil 2013). Because of the lack of efficacy, the widespread use of unmodified $\mathrm{AWBs}$ for decontaminating $\mathrm{PO}_{4}{ }^{3-}$ from wastewater is still limited.

\subsubsection{Phosphorus Adsorption Performance by Modified AWBs}

Most of unmodified AWBs are inefficient in decontamination of $\mathrm{P}$ from water and wastewater. The reason is supposed to be the lack of anion binding sites on the AWBs surface. Thus, to improve the affinity of AWBs towards P, AWBs need to be cationized (Nguyen et al. 2012; Mallampati and Valiyaveettil 2013). This could be done via metal loading, hybridizing with inorganic chemicals, and grafting with ammonium type chemicals (Han et al. 2005).

Among these methods, metal loading appears to be preferred, because of its simplicity and effectiveness. It was found that metal oxides (e.g. Fe, Al, Mn, etc.) in some low-cost materials played important roles in their $\mathrm{PO}_{4}^{3-}$ retention capability (Penn et al. 2007; Liu et al. 2012). These may suggest a solution for the enhancement of $\mathrm{P}$ uptake in AWBs, which is metal impregnation. It was assumed that metals can be deposited on the surface of AWBs via chemical interactions e.g. substitution for $\mathrm{Ca}$ (II) or binding onto active sites (Han et al. 2005). It is expected that metal treated AWBs with high positive charges can sequester effectively $\mathrm{PO}_{4}{ }^{3-}$ anions (Cheng et al. 2013). The common metals used for cationization of AWBs include $\mathrm{Zn}$ (II), Fe(II, III), $\mathrm{La}$ (III), $\mathrm{Ce}(\mathrm{III}), \mathrm{Zr}(\mathrm{IV})$. These metals can be used alone or in combination (Eljamal et al. 2013). Each metal has its own merits and demerits when used as modifiers of AWBs. While $\mathrm{La}(\mathrm{III})$ has a high affinity toward $\mathrm{PO}_{4}{ }^{3-}$ anions and non toxicity, it suffers from drawbacks associated with the limited reusability (Zhang et al. 2011). $\mathrm{Zr}(\mathrm{IV})$ possesses favorable characteristics, such as high affinity and selectivity, large surface area, and chemical stability. Nevertheless, high cost is a critical factor, limiting its commercial application in $\mathrm{PO}_{4}{ }^{3-}$ removal (Mallampati et al. 2013). Similarly, though the properties of cheapness, easy acquiring and non-hazardousness enable the use of Fe(II, III) for this purpose, their week point is less sorption efficiency. Based on this, it seems to be a good idea to use loading metals collectively to make use of their advantages while mitigating their drawbacks (Ren et al. 2012). Some researchers have treated raw AWBs directly with metal solutions, e.g. Han et al. (2005); Krishnan and Haridas (2008); Huang et al. (2009); Kose and Kivanc (2011); Mallampati and Valiyaveettil (2013). Krishnan and Haridas (2008) found that, the maximum $\mathrm{PO}_{4}{ }^{3-}$ adsorption capacity of $\mathrm{Fe}$ impregnated coir pith (CP-Fe-I) was improved 5-6 times as compared to natural coir pith (CP), owing to iron impregnation. The adsorption capacity of AWBs directly loaded with metals was in the range of 7.08-23.02 $\mathrm{mg} / \mathrm{g}$ (Table 14.5). These values were found to be in the same order of magnitude as those achieved for modified conventional adsorbents $(0.88-14.12 \mathrm{mg} / \mathrm{g})$, but still far lower when compared with many commercial adsorbents (27.73-131.77 $\mathrm{mg} / \mathrm{g}$ ) (Table 14.4). To further improve the $\mathrm{P}$ uptake capacity of modified AWBs, efforts have been directed toward strengthening the 
anchor of metals on the surface of AWBs via reactions with carboxylation or bases. Eberhardt and Min (2008) explored that the $\mathrm{PO}_{4}{ }^{3-}$ adsorption capacity by wood particles modified by carboxymethylation and Fe(II) was 8.47 times higher than that of wood particles pretreated with Fe(II) alone. Similar observation was noticed by Carvalho et al. (2011). They reported that due to carboxymethylation, the adsorption capacity of Fe(II) by sugarcane bagasse fibers was boosted $371.25 \%$.

This was supposed to be responsible for a rise in the $\mathrm{PO}_{4}{ }^{3-}$ removal efficiency, from 94 to 97\%. In their 2007 and 2008 studies, Biswas (2008) used $\mathrm{Ca}(\mathrm{OH})_{2}$ and $\mathrm{NaOH}$ to enhance the incorporation of $\mathrm{La}(\mathrm{III}), \mathrm{Ce}(\mathrm{III}), \mathrm{Fe}(\mathrm{III})$ and $\mathrm{Zr}(\mathrm{IV})$ into orange waste. The modified orange waste gels displayed satisfactory sorption behaviors. The $\mathrm{PO}_{4}{ }^{3-}$ uptake capacity reached as high as $42.72 \mathrm{mg} / \mathrm{g}$ for gels loaded with $\mathrm{La}(\mathrm{III})$, $\mathrm{Ce}(\mathrm{III})$ and $\mathrm{Fe}(\mathrm{III})$ and $174.68 \mathrm{mg} / \mathrm{g}$ for gels loaded with $\mathrm{Zr}(\mathrm{IV})$. The former can be in competition with some modified adsorbents while the latter is superior to all commercial adsorbents given in Table 14.4. The effectiveness of metal loaded AWBs is found to rely on the type and concentration of metal solutions as well as method of metal loading onto the AWBs surface. Wang et al. (2012) reported that AC/N-Fe(II) exhibited better adsorption capacity for $\mathrm{PO}_{4}{ }^{3-}$ than $\mathrm{AC} / \mathrm{N}-\mathrm{Fe}(\mathrm{III})$. The authors ascribed this to higher intra-particle diffusion and binding energy of $\mathrm{AC} / \mathrm{N}-\mathrm{Fe}$ (II) in comparison with $\mathrm{AC} / \mathrm{N}-\mathrm{Fe}(\mathrm{III})$. Shin et al. (2005) found that the level of $\mathrm{PO}_{4}{ }^{3-}$ capture by $\mathrm{La}$ (III) loaded juniper bark fiber was improved from 20.05 to $33.35 \mathrm{mg} / \mathrm{g}$ as the concentration of $\mathrm{La}\left(\mathrm{NO}_{3}\right)_{3} \cdot 6 \mathrm{H}_{2} \mathrm{O}$ increased from $0.01 \mathrm{M}$ to $0.1 \mathrm{M}$. Nada and Hassan (2006) revealed that etherification was more efficient than oxidation and esterification in deposition of all four investigated heavy metals (i.e., $\mathrm{Cu}, \mathrm{Fe}, \mathrm{Ni}, \mathrm{Cr}$ ) onto carboxymethyl cellulose.

Another way to cationize AWBs is quarternization. This can be done via reactions between hydroxyl $\left(\mathrm{OH}^{-}\right)$groups in AWBs with amines $\left(-\mathrm{NH}_{2}\right)$ groups in quaternary ammonium compounds (Nada and Hassan 2006; Karachalios 2012; Karachalios 2012). This process includes two steps, namely cross-linking and quaternizing (Marshall and Wartelle 2004). Quartenization improves the $\mathrm{PO}_{4}{ }^{3-}$ adsorption capacity of raw AWBs, possibly owing to better anion exchange capacity (Wang et al. 2010), larger surface area and higher number of amine groups (Xu et al. 2010). Various quaternizing reagents have been tested for this purpose, e.g. dimethylamine (Anirudhan et al. 2006); urea (Benyoucef and Amrani 2011; Karachalios 2012); 2-hidroxypropyltrimethyl ammonium chloride (De Lima et al. 2012); polyallylamine hydrochloride (Karthikeyan et al. 2004); trimethylammoniumchloride (Marshall and Wartelle 2004; Wartelle and Marshall 2006); ethylenediamine \& triethylamine (Wang et al. 2010; Yue et al. 2010; Xu et al. 2011a), etc. In most cases, quaternized AWBs exhibited the enhanced adsorption capacities for $\mathrm{PO}_{4}{ }^{3-}$ as compared to raw AWBs. Zhang et al. (2012) revealed that the $\mathrm{PO}_{4}{ }^{3-}$ uptake capacity of quarternized sugarcane bagasse (MSBG) and raw sugarcane bagasse (SBG) was 21.30 and $1.1 \mathrm{mg} / \mathrm{g}$, respectively. They explained this by the difference in the zeta potential between MSBG $(32 \mathrm{mV})$ and SBG $(-22 \mathrm{mV})$ after quarternization. Due to electrostatic interactions, the former favored the retention of 
$\mathrm{PO}_{4}{ }^{3-}$, whilst the latter hinder the adsorption process. Similarly, Xu et al. (2009) found that modified wheat residue showed greatly higher $\mathrm{PO}_{4}{ }^{3-}$ removal efficiency (92.5\%) than raw wheat residue (4.8\%). In a more recent study, Xu et al. (2011a) reported that amine grafted giant reed showed an extremely high $\mathrm{PO}_{4}{ }^{3-}$ adsorption capacity $(54.67 \mathrm{mg} / \mathrm{g})$ as compared with raw giant reed $(0.863 \mathrm{mg} / \mathrm{g})$. It is interesting to note that quaternization of banana stem not only improved $\mathrm{PO}_{4}{ }^{3-}$ removal efficiency by $25.8 \%$, but also reduced COD by $83.40 \%$ as compared to raw materials (Anirudhan et al. 2006). Compared to some well-known commercial adsorbents (3.36-131.77 mg/g), comparable and higher adsorption capacities could be obtained with quaternized AWBs $(45.7-205.63 \mathrm{mg} / \mathrm{g}$ ) (Tables $14.4,14.5)$. The extremely good adsorption capacity for $\mathrm{PO}_{4}{ }^{3-}$ makes quaternized $\mathrm{AWBs}$ attractive for practical application. In view of searching potential AWBs for quaternization, Wartelle and Marshall (2006) recommended to use AWBs with low lignin-to-cellulose ratios, because of their strong affinity toward quarternizing reagents. These results highlight the potential of improvement of $\mathrm{PO}_{4}{ }^{3-}$ uptake capacity of $\mathrm{AWBs}$ using quaternization.

In addition to metal loading and quaternization, thermal activation is shown to be efficient in boosting the P removal. Huang et al. (2010) found that preheating oyster shell in the temperature range of significantly $100-400{ }^{\circ} \mathrm{C}$ improved its adsorption capacity for $\mathrm{PO}_{4}{ }^{3-}$ ions. While untreated oyster shells could hardly remove $\mathrm{PO}_{4}{ }^{3-}$ from $80 \mathrm{~mL}$ wastewater with $\mathrm{PO}_{4}{ }^{3-}$ concentration of $20 \mathrm{~g} / \mathrm{L}$, the removal efficiency of preheated oyster shells reached up to $100 \%$ after 3 or 4 days. This is attributed to the increase in the pore size and surface area. The temperature range of 500-700 ${ }^{\circ} \mathrm{C}$ resulted in the decrease in the $\mathrm{P}$ removal efficiency, owing to the collapse of pore structure while lack of $\mathrm{CaCO}_{3}$ decomposition. The $\mathrm{P}$ removal percent increased again as temperature increased from 750 to $900{ }^{\circ} \mathrm{C}$. This can be explained by the dominant presence of $\mathrm{CaO}$, which plays an important role in the adsorption of $\mathrm{PO}_{4}{ }^{3-}$. Peng et al. (2012) found that better $\mathrm{PO}_{4}{ }^{3-}$ uptake was achieved for pine sawdust char (BC) produced at the higher pyrolysis temperature. The maximum adsorption capacity of BC is comparable to Whatman QA -52 and higher-when compared with Zr-MCM 41. 
Table 14.5. A summary on modification methods for developing better AWBs

\begin{tabular}{|c|c|c|c|}
\hline Biosorbent & Modifying reagents & $\begin{array}{l}\text { Maximum adsorption } \\
\text { capacity }\left(\mathrm{mg} \mathrm{PO}_{4}{ }^{3-} / \mathrm{g}\right)\end{array}$ & References \\
\hline \multicolumn{4}{|l|}{ Metal impregnation } \\
\hline Wood particles & $\mathrm{Fe}(\mathrm{II}) \mathrm{salt}$ & 2.05 & Eberhardt and Min (2008) \\
\hline Coir pith carbon & $\mathrm{Zn}(\mathrm{II})$ salt & 5.10 & Namasivayam and Sangeetha (2004) \\
\hline Juniper fiber & Acid mine drainage (AMD) & 7.08 & Han et al. (2005) \\
\hline Wood particles & Carboxymethylation $+\mathrm{FeCl}_{2}$ & 17.38 & Eberhardt and Min (2008) \\
\hline Juniper bark fiber & $\mathrm{La}\left(\mathrm{NO}_{3}\right)_{3} \cdot 6 \mathrm{H}_{2} \mathrm{O} 0.01 \mathrm{M}$ & 20.05 & Shin et al. (2005) \\
\hline Apple peel & $\mathrm{ZrO}_{2} \mathrm{Cl} .8 \mathrm{H}_{2} \mathrm{O}$ & 20.35 & Mallampati and Valiyaveettil (2013) \\
\hline Skin split waste & $\mathrm{Al}(\mathrm{III})$ salt & 21.65 & Huang et al. (2009) \\
\hline Coir pith & $\mathrm{Fe}\left(\mathrm{NO}_{3}\right)_{3} .9 \mathrm{H}_{2} \mathrm{O}$ & 22.05 & Krishnan and Haridas (2008) \\
\hline Eggshell & Calcination & 23.02 & Kose and Kivanc (2011) \\
\hline Juniper bark fiber & $\mathrm{La}\left(\mathrm{NO}_{3}\right)_{3} .6 \mathrm{H}_{2} \mathrm{O} 0.1 \mathrm{M}$ & 33.35 & Shin et al. (2005) \\
\hline Orange waste & $\mathrm{Ca}(\mathrm{OH})_{2}+\mathrm{La}(\mathrm{III}) / \mathrm{Ce}(\mathrm{III}) / \mathrm{Fe}(\mathrm{III})$ salts & 42.72 for 3 types of gels & Biswas et al. (2007) \\
\hline $\begin{array}{l}\text { Sugarcane baggage } \\
\text { fibers }\end{array}$ & Carboxymethylation & 67.50 & Carvalho et al. (2011) \\
\hline Skin split waste & Fe(III) salt & 72.00 & Huang et al. (2009) \\
\hline $\begin{array}{l}\text { Sugarcane baggage } \\
\text { fibers }\end{array}$ & Carboxymethylation $+\mathrm{FeCl}_{2}$ & 152.00 & Carvalho et al. (2011) \\
\hline $\begin{array}{l}\text { Orange waste gel } \\
\text { Quarternization }\end{array}$ & $\mathrm{Ca}(\mathrm{OH})_{2}+\mathrm{NaOH}+\mathrm{Zr}(\mathrm{IV})$ salt & 174.68 & Biswas (2008) \\
\hline Milled pine bark & $\begin{array}{l}\text { Poly-allylamine hydrochloride (PAA HCl) + } \\
\text { Epichlorohydrin }\end{array}$ & 12.65 & Tshabalala et al. (2004) \\
\hline $\begin{array}{l}\text { Wheat residue (Low/ } \\
\text { medium/ high cost } \\
\text { resins) }\end{array}$ & $\begin{array}{l}\text { Epichlohydrin + N,N-Dimethylformamide + } \\
\text { Ethylenediamine + Triethylamine }\end{array}$ & $16.50 / 32.05 / 52.40$ & Xu et al. (2011c) \\
\hline Soybean hulls & $\begin{array}{l}\text { N-(3-chloro-2-hydroxypropyl) }+ \\
\text { Trimethylammonium chloride }\end{array}$ & 19.84 & Marshall and Wartelle (2004) \\
\hline
\end{tabular}


Table 14.5. Continued

\begin{tabular}{|c|c|c|c|}
\hline Biosorbent & Modifying reagents & $\begin{array}{l}\text { Maximum adsorption } \\
\text { capacity }\left(\mathrm{mg} \mathrm{PO}_{4}{ }^{3-} / \mathrm{g}\right)\end{array}$ & References \\
\hline \multicolumn{4}{|l|}{ Quarternization } \\
\hline Sugarcane bagasse & $\begin{array}{l}\text { Epichlorohydrin }+ \text { N,N-Dimethylformamide }+ \\
\text { Dimethylamine + Pyridine }\end{array}$ & 21.30 & Zhang et al. (2012) \\
\hline Milled woods/ bark & $\begin{array}{l}\text { Poly-allylamine hydrochloride (PAA HCl) + } \\
\text { Epichlorohydrin }\end{array}$ & $26.03 / 44.65$ & Karthikeyan et al. (2004) \\
\hline $\begin{array}{l}\text { Yellow pine (wood/ } \\
\text { bark) }\end{array}$ & $\begin{array}{l}\text { Poly-allylamine hydrochloride (PAA-HCl) or } 3 \\
\text { chloro -2- hydroxypropyltrimethylammonium } \\
\text { chloride }\end{array}$ & $22.83 / 36.65$ & Karthikeyan et al. (2002) \\
\hline Wheat straw & Epichlorohydrin + Triethylamine + Pyridine & 45.70 & Xu et al. (2010) \\
\hline $\begin{array}{l}\text { Cotton stalk/ wheat } \\
\text { stalk }\end{array}$ & $\begin{array}{l}\text { Epichlorohydrin }+ \text { N,N-Dimethylformamide }+ \\
\text { Diethylenetriamine }+ \text { Trimethylamine }\end{array}$ & $51.54 / 60.61$ & $\mathrm{Xu}$ et al. (2011b) \\
\hline Giant reed & $\begin{array}{l}\text { Epichlohydrin + N,N-Dimethylformamide + } \\
\text { Ethylenediamine + Triethylamine }\end{array}$ & 54.67 & Xu et al. (2011a) \\
\hline Giant reed & $\begin{array}{l}\text { Epichlohydrin + N,N-Dimethylformamide + } \\
\text { Ethylenediamine + Triethylamine }\end{array}$ & 60.95 & Yue et al. (2010) \\
\hline Corn stover & $\begin{array}{l}\mathrm{N}-(3 \text {-chloro-2-hydroxypropyl) }+ \\
\text { Trimethylammonium chloride }\end{array}$ & 62.70 & Watelle and Marshall (2006) \\
\hline Banana stem & $\begin{array}{l}\text { Epichlorohydrin }+ \text { N,N-Dimethylformamide }+ \\
\text { Dimethylamine + Pyridine }\end{array}$ & 72.46 & Anirudhan e al. (2006) \\
\hline $\begin{array}{l}\text { Sawdust of Aleppo } \\
\text { pine }\end{array}$ & $\begin{array}{l}\text { Surface activation, acid prehydrolysis, urea } \\
\text { treatment }\end{array}$ & 116.25 & Benyoucef and Amrani (2011) \\
\hline $\begin{array}{l}\text { Green coconut shell } \\
\text { fibers }\end{array}$ & $\begin{array}{l}\text { Ammonium quaternary salt ( } 2- \\
\text { hidroxypropyltrimethyl ammonium chloride) }\end{array}$ & 200.00 & De Lima et al. (2012) \\
\hline $\begin{array}{l}\text { Wood residues } \\
\text { Thermal activation }\end{array}$ & Choline chloride derivative + Urea + Imidazole & 205.63 & Karachalios (2012) \\
\hline Pine sawdust char & Fast pyrolysis & 15.11 & Peng et al. 2012 \\
\hline
\end{tabular}




\subsubsection{Phosphorus Recovery}

\subsubsection{Drivers for Phosphorus Recovery}

The $\mathrm{P}$ recovery is becoming a matter of interest in recent years. There are several drives for this. Firstly, the $\mathrm{P}$ recovery can contribute to conserving the global $P$ rock reserves, which will be depleted within 150 years (Tyagi and Lo 2013; Loganathan et al. 2014). As the recycled $\mathrm{P}$ can replace the mineral $\mathrm{P}$ used in agriculture and phosphate industry, the $\mathrm{P}$ recovery is expected to diminish the amount of $\mathrm{P}$ rock mined annually, which is estimated at 160 million tons (Cornel and Schaum 2009; Kuzma 2011; Kalmykova and Fedje 2013). Secondly, the P recovery can protect the water environment from eutrophication by reducing $\mathrm{P}$ concentration in effluents. The increasing use of recycled $\mathrm{P}$ products as slow release fertilizers in the agriculture reduces the risk of $\mathrm{P}$ leaching and loss, and thus indirectly mitigating the eutrophication (Garcia-Belinchon et al. 2013). Moreover, the P recovery can create revenues by converting waste into commercial products. It is estimated that the $\mathrm{P}$ recovery from sewage sludge can produce a profit of about US\$2.1 per capita and year (Tyagi and Lo 2013). Finally, this process may prevent struvite scale, which is a threat to most of the engineered systems (Kuzma 2011).

\subsubsection{Phosphorus Recovery Technologies}

Till date, various technologies are available for $\mathrm{P}$ recovery. Depending on the WWTPs products (water, sludge or ash) utilized for $\mathrm{P}$ recovery, the $\mathrm{P}$ recovery technology can be precipitation/crystallization, wet-chemical or thermo-chemical, respectively (Figure 14.4). Due to very low P concentration $(\leq 5 \mathrm{mg} / \mathrm{L}$ ), effluents of WWTPs cannot be a good source, as high volume needs to be treated. On the contrary, the higher $\mathrm{P}$ concentration $(20-100 \mathrm{mg} / \mathrm{L})$ in the sludge liquor reduces the volume to be treated, and thus this product is widely used (Schick et al. 2009). As P in the sludge and ash is biologically/chemically bonded to other substances, it needs to be extracted by acids or bases before being separated by means of precipitation, ion exchange, nanofiltration, etc. This is the principle of wet-chemical technology. By using chlorine compounds (e.g. $\left.\mathrm{KCl}, \mathrm{MgCl}_{2}\right)$ and high temperature $\left(>1000{ }^{\circ} \mathrm{C}\right.$ ), thermo-chemical technology is expected to remove heavy metals in the form of vaporized heavy metals chlorides, and thus enabling $\mathrm{P}$ separation. The $\mathrm{P}$ recovery potential may vary, depending on the utilized WWTPs products. While the recovery rate from the water phase is limited to $55 \%$, the values from sewage sludge and ash can reach 90\% (Cornel and Schaum 2009; Nieminen 2010). Among influential factors, $\mathrm{pH}$ and molar ratios of $\mathrm{Mg}^{2+}, \mathrm{NH}_{4}{ }^{+}$, and $\mathrm{PO}_{4}{ }^{3-}$ are found to play the critical roles in the P recovery process (Liu et al. 2012). The most common products of this process are magnesium ammonium phosphate (MAP, struvite) and calcium phosphate (Cornel and Schaum 2009). 


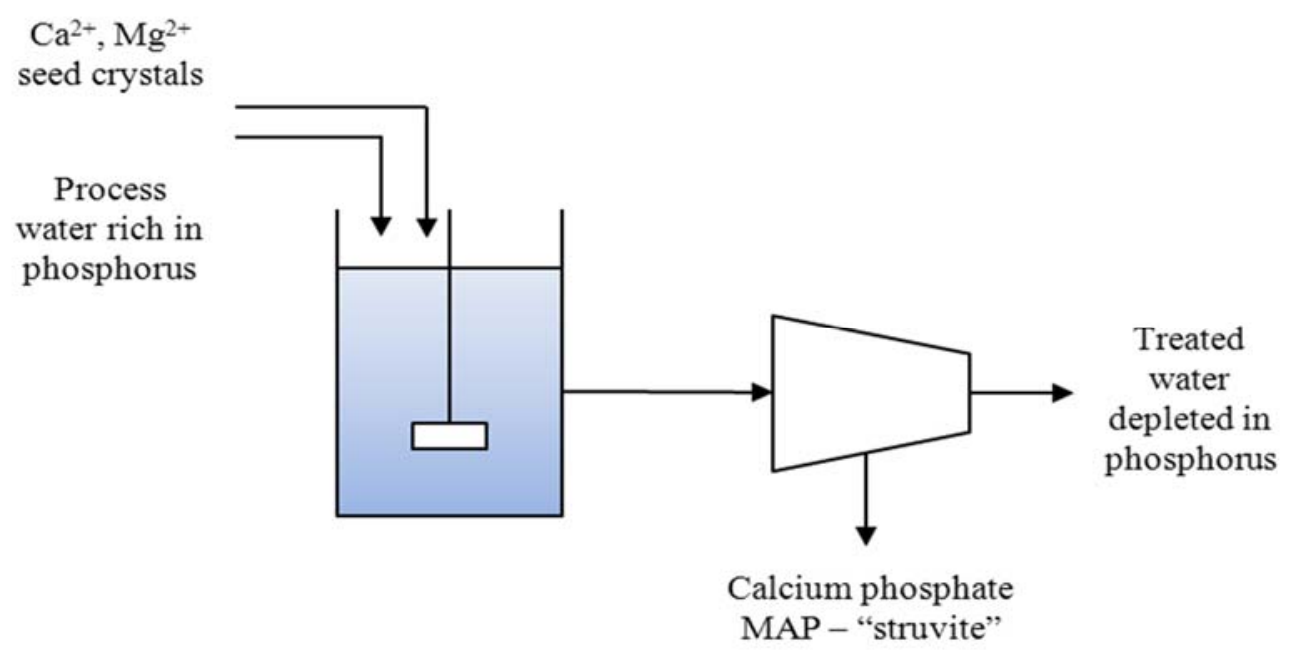

(a) The principle of precipitation/crystallization technologies (Cornel at al. 2011)

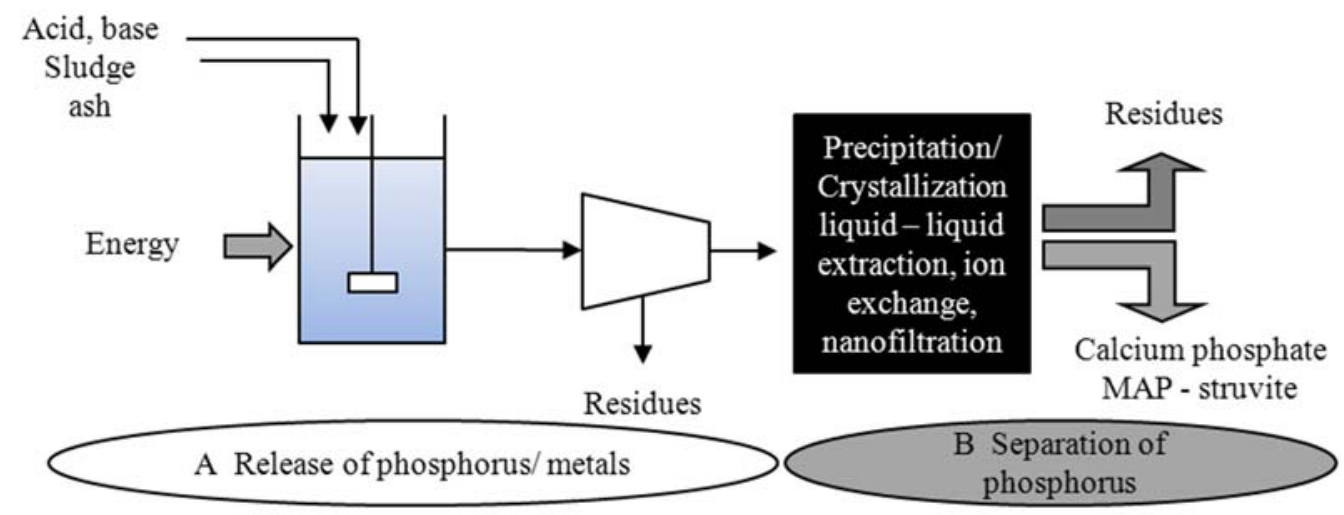

(b) The principle of wet-chemical technology (Cornel et al. 2011)

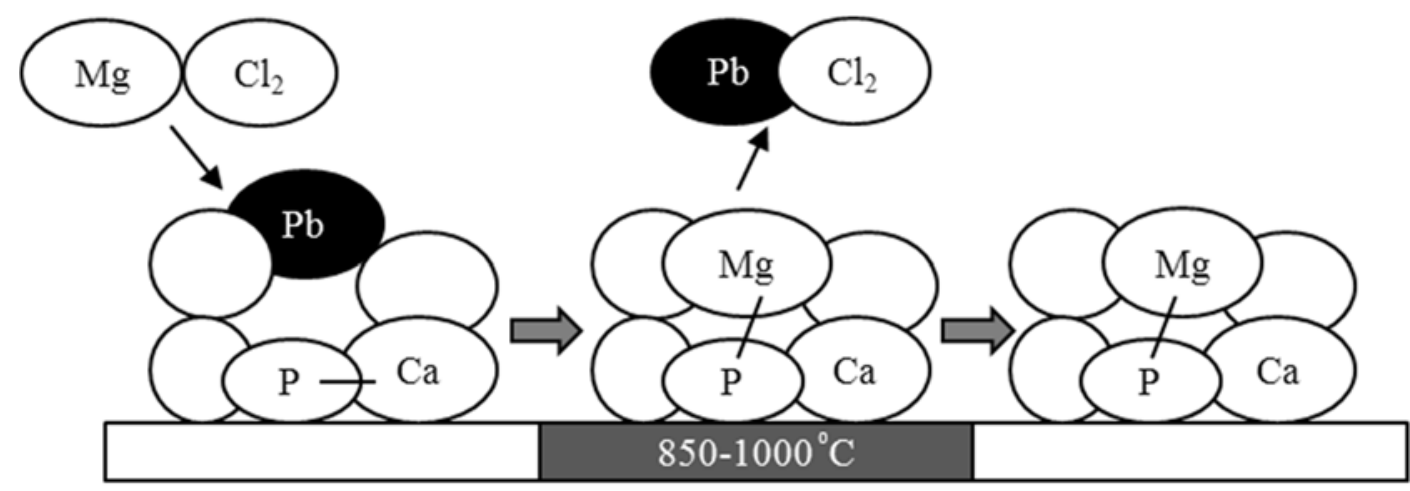

(c) The principle of thermo-chemical technology (adapted from Adam 2011)

Figure 14.4. Phosphorus recovery technologies 


\subsubsection{Phosphorus Recovery by Means of Adsorption}

$\mathrm{P}$ recovery is defined as the utilization of any process for precipitating or crystallizing $\mathrm{P}$ from wastewater, sewage sludge, and ash into a pure product for recycling purposes (Green et al. 2004). Although P recovery as struvite or calcium phosphate is widely known, only a few reports exist on the use of adsorption for this purpose. Ebie et al. (2008) investigated the $\mathrm{P}$ recovery in decentralized advanced Johkasou by means of adsorption onto $\mathrm{Zr}$ (IV). The spent adsorbent was immersed in the $\mathrm{NaOH} 7 \%$ solution to elute P. Because of the two-step desorption process, the desorption efficiency was enhanced from 80 to $95 \%$. The maximum recovery efficiency $(95.6 \%)$ was achieved by crystallization using low-temperature concentrator in vacuo. The recovered $\mathrm{P}$ product $\left(\mathrm{Na}_{3.25}(\mathrm{OH})_{0.25} \mathrm{PO}_{4.12} \mathrm{H}_{2} \mathrm{O}\right)$ had the purity of $>95 \%$ with the permissible levels of hazardous elements (e.g. $\mathrm{As}, \mathrm{Hg}, \mathrm{Pb}$, $\mathrm{Cd}$, and $\mathrm{Ni}$ ). The tests on germination rate and fertilizer response showed that recovered $\mathrm{P}$ was as good as $\mathrm{Na}_{2} \mathrm{HPO}_{4}$, a chemical fertilizer. As the elution solution after crystallization was recycled as a desorbent, the chemical costs and the disposal problems could be mitigated. Similarly, Midorikawa et al. (2008) utilized a highspeed adsorbent for P recovery from municipal wastewater secondary effluent. Due to the particularly high removal percentage (99.5\%) and desorption efficiency (97\%) of this adsorbent, $\mathrm{P}$ was successfully separated. $\mathrm{Ca}(\mathrm{OH})_{2}$ was added to precipitate eluted $\mathrm{P}$ as calcium phosphate. With $16 \% \mathrm{P}$ and very low levels of toxic substances, the recovered product could be used as a replacement for $\mathrm{P}$ ore and fertilizer. The works on $\mathrm{P}$ recovery via a combination of biosorption onto AWBs and precipitation/crystallization are rare. Most of the studies are limited to desorption of $\mathrm{P}$ and reusability of AWBs. It was found that some AWBs possessed very high desorption efficiencies with good reusability, e.g. modified banana stem (Anirudhan et al. 2006); $\mathrm{Zr}$ (IV) loaded orange waste gel (Biswas 2008); $\mathrm{Zr}$ (IV) loaded apple peels (Mallampati et al. 2013); modified sugarcane bagasse (Zhang et al. 2012), etc. Unfortunately, these AWBs have not been used in combination with precipitation/crystallization for $\mathrm{P}$ recovery.

Biswas (2008) claimed that $\mathrm{P}$ could be efficiently extracted from incinerated sewage sludge ash (ISSA) using $0.05 \mathrm{M} \mathrm{H}_{2} \mathrm{SO}_{4}$ or $0.1 \mathrm{M} \mathrm{HCl}$. Due to the selective adsorption onto $\mathrm{Zr}(\mathrm{IV})$ loaded orange waste gel, the extracted $\mathrm{P}$ was separated from other contaminants, e.g. $\mathrm{Ca}, \mathrm{Fe}, \mathrm{Al}$, etc. The adsorbed $\mathrm{P}$ could be easily eluted using $\mathrm{NaOH} 0.2 \mathrm{M}$. That paves the way to the recovery of $\mathrm{P}$ from ISSA. Kose and Kivanc (2011) proposed a procedure whereby the $\mathrm{P}$ eluted from calcined waste eggshell by $\mathrm{NaOH} 0.5 \mathrm{M}$ could be recovered as calcium phosphate by the addition of solid $\mathrm{CaO}$. Desorption and recovery efficiencies of $\mathrm{P}$ were $37.6 \%$ and $37.72 \%$, respectively. It is inferred from the obtained results that, adsorption may hold a promise for $\mathrm{P}$ recovery from wastewater, but it has not been fully exploited. Based on published results, a diagram of $\mathrm{P}$ removal/recovery from wastewater by means of adsorption onto AWBs is proposed (Figure 14.5). 


\subsubsection{Barriers for Phosphorus Recovery}

Until now, $\mathrm{P}$ recovery is still an un-established process. The reason for this remains in the quality of recycled $P$ fertilizers (Sartorius et al. 2012). The excessive level of heavy metals in $\mathrm{P}$ fertilizers recovered from municipal solid waste incineration fly ash prevents them from being used in arable lands (Kalmykova and Fedje 2013). In addition, recycled $\mathrm{P}$ seems to be more expensive than mineral $\mathrm{P}$ (Cornel and Schaum 2009). The cost for $\mathrm{P}$ recovered from sludge liquor by ion exchange was $8.2 € / \mathrm{kg}$ while that for mined P was only $0.652 € / \mathrm{kg}$ (Bottini and Rizzo 2012). These findings are in harmony with those reported by Tyagi and Lo (2013), who claimed that recovered $\mathrm{P}$ was 22 times more costly than mined P. MolinosSenante et al. (2011) suggested that the P recovery would not be a financially viable option, unless the environmental benefits were considered. These constraints are expected to be addressed in the next 20 years in developed countries (Sartorius et al. 2012).

\subsubsection{Selection of Potential AWBs for P Removal and Recovery}

The selection of proper AWBs for $\mathrm{PO}_{4}{ }^{3-}$ removal/recovery plays an important role as it may affect the whole process. However, up to date, little work has been done on building the guideline for this. Consequently, while one AWB can be successfully tested in the lab, unexpected results can be obtained from its practical application. Thus, this section briefly discusses key criteria for screening potential AWBs in $\mathrm{PO}_{4}{ }^{3-}$ removal/recovery.

It is well recognized that the main advantage of biosorbents as compared to other methods is their "cost-effectiveness" (Srivastava and Goyal 2010; Everglades hub 2013). Hence, this should be considered as a fundamental principle in selecting potential adsorbing materials. As mentioned above, the removal and recovery of $\mathrm{PO}_{4}{ }^{3-}$ from wastewater using $\mathrm{AWBs}$ includes two steps: the separation of $\mathrm{PO}_{4}{ }^{3-}$ followed by the precipitation/crystallization of $\mathrm{PO}_{4}{ }^{3-}$. While the first step can be done via selective adsorption with AWBs, the second step can be accomplished by using $\mathrm{Ca}(\mathrm{OH})_{2}, \mathrm{CaCl}_{2}$, etc. For that reason, ideal AWBs should have high affinity toward $\mathrm{PO}_{4}{ }^{3-}$ anions to ensure their efficient removal. As raw AWBs are often prone to less adsorption efficiency, modification methods are required to improve $\mathrm{PO}_{4}{ }^{3-}$ uptake capacity of raw AWBs. In addition, high selectivity is needed for separation of $\mathrm{PO}_{4}{ }^{3-}$ anions from other pollutants. Moreover, easy desorption property may be necessary as it paves the way to $\mathrm{P}$ recovery. It should be noted that, these properties are necessary but not adequate for successful removal/recovery of $\mathrm{PO}_{4}{ }^{3-}$. Penn et al. (2007) suggested that while the cost and availability should be considered, in view of large scale application, the particle size or hydraulic properties may be significant if AWBs are used in the column mode. Similarly, Srivastava and Goyal (2010) highlighted reusability property as an efficient way to make the process cost-saving. Accordingly, ideal AWBs should have no physical damage, minor diminished $\mathrm{P}$ uptake, marginal weight loss, trivial loaded metal leakage, etc. after many cycles of 
adsorption and desorption. In the same way, Loganathan et al. (2014) suggested that suitable adsorbents for $\mathrm{P}$ removal/recovery should have a high sorption capacity, good hydrological conductivity and easy regeneration and proper reuse. Besides these things, from our own experience, we highly recommend that appropriate AWBs should not cause any significant detrimental effects on the quality of aqueous solutions (e.g. color, turbidity, DO, COD, BOD, heavy metals, etc.).

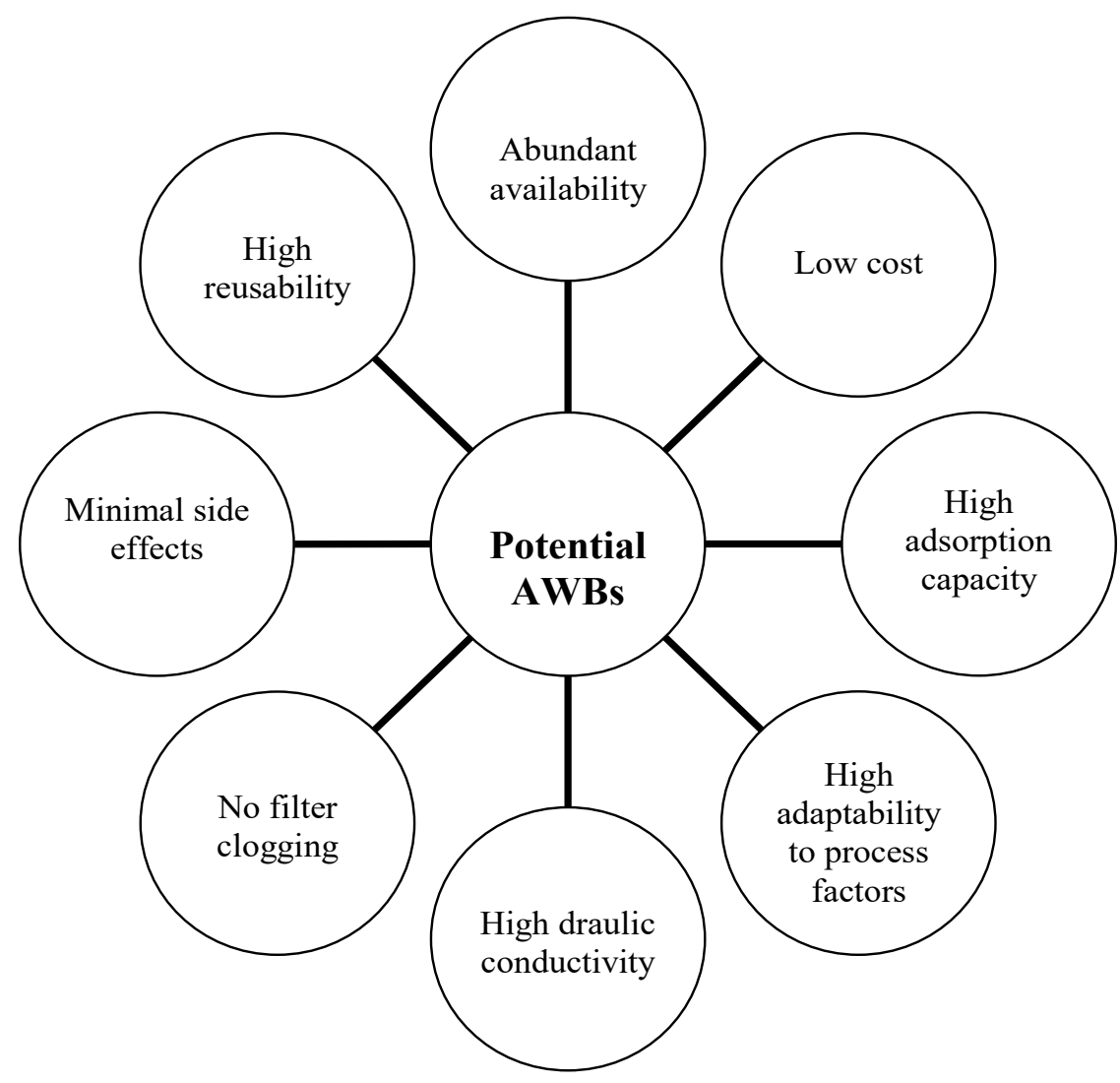

Figure 14.6. Selection criteria of potential AWBs used for P removal/recovery

Regarding the availability characteristic of AWBs, we suggest using wastes or by-products from food processing industries (e.g. orange peel, sugarcane bagasse, soybean milk residues, etc.) for developing potential AWBs, due to their stable quality and supply source. Keeping the above views in mind, appropriate AWBs for $\mathrm{P}$ removal/recovery should own the following properties:

- $\quad$ Abundant availability;

- Low cost;

- $\quad$ High affinity toward $\mathrm{PO}_{4}^{3-}$;

- $\quad$ High adaptability toward process parameters;

- $\quad$ High reusability;

- $\quad$ High hydraulic conductivity;

- $\quad$ No filter clogging; and

- Minimal side effects to the water environment. 


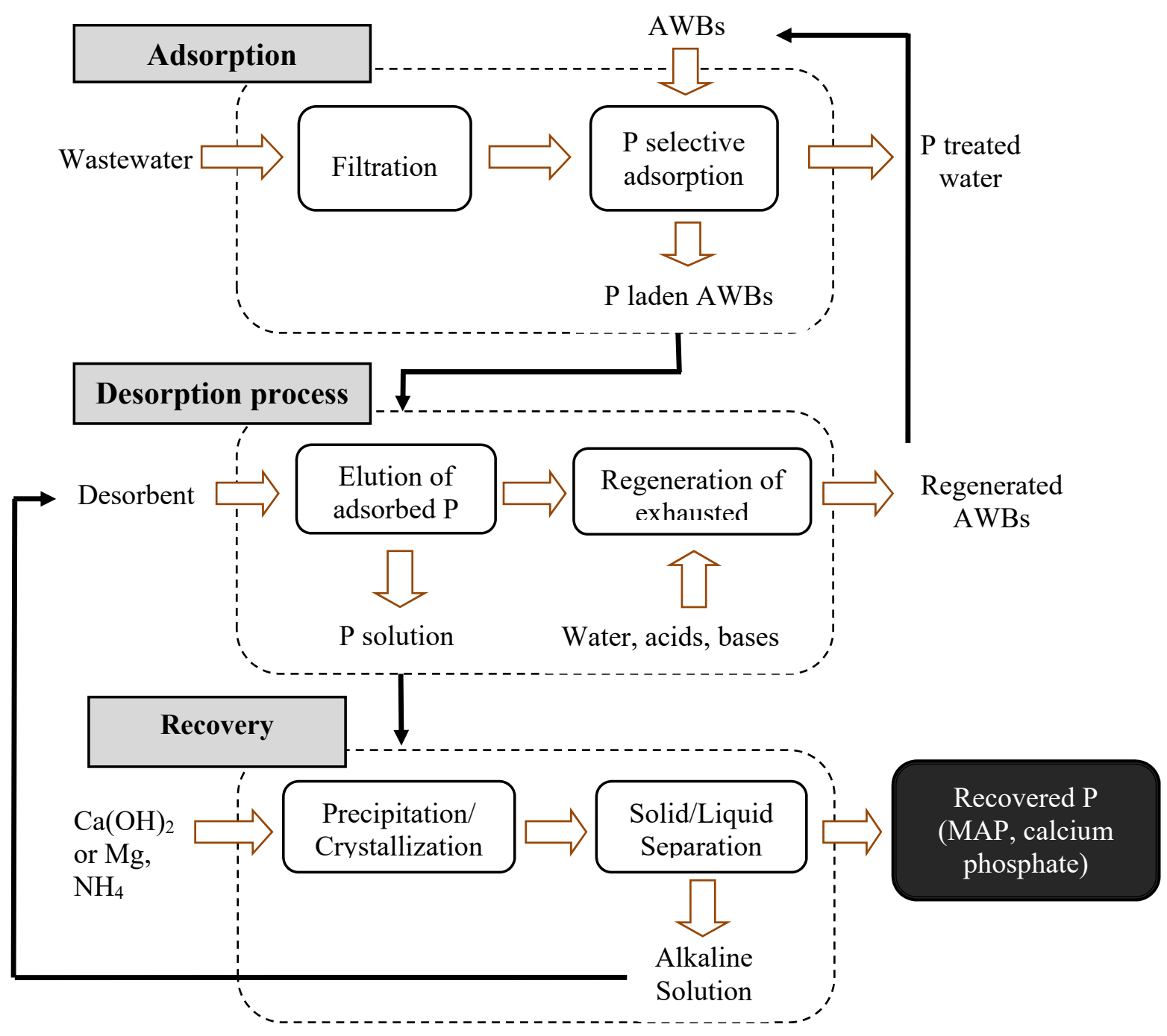

Figure 14.5. Diagram of $P$ removal/recovery from water and wastewater via adsorption onto AWBs 


\subsection{Recent Advances}

The adsorptive removal and recovery of $\mathrm{PO}^{3-}$ from water and wastewater using AWBs is a relatively new process. In the initial stage of its development, the results obtained mainly focus on basic knowledge. Understanding the operation principles is expected to enable the application of AWBs in the future. The recent developments drawn from studies on removal and recovery of $\mathrm{PO}^{3-}$ from water and wastewater using AWBs include:

- $\quad$ Confirming that raw AWBs are frequently inefficient in $\mathrm{P}$ removal and thus satisfactory decontamination of $\mathrm{P}$ requires appropriate modifications. The common methods are found to be metal loading and quaternization of AWBs. Side effects of modifying AWBs are also identified;

- $\quad$ Some potential AWBs have been found, mainly based on the maximum adsorption capacity;

- The mechanisms of the adsorption/desorption processes have been initially elucidated. This provides useful information for process optimization and selection of appropriate desorption solutions;

- $\quad$ The effects of process parameters have been investigated in an attempt to comprehend and optimize the process. For example, understanding the effect of $\mathrm{pH}$ can help to explain the desorption mechanism and choose the appropriate desorption solutions, whereas identification of the effect of particle sizes, contact time, interfering anions, etc. on the adsorption of $\mathrm{P}$ onto AWBs is necessary for their practical application; and

- $\quad$ The recovery of $\mathrm{P}$ based on the combination of adsorption onto AWBs and precipitation/ crystallization is initially investigated in the labs.

\subsection{Conclusion and Future Work}

Due to increasing concerns relevant to water quality deterioration and depletion of global $\mathrm{P}$ rock reserves, the $\mathrm{P}$ removal/recovery has recently become a matter of interest. Even though various technologies are presently available, adsorption seems to have advantages when used for $\mathrm{P}$ recovery. Due to selective adsorption property of AWBs, $\mathrm{P}$ can be separated from other contaminants and thus enabling $\mathrm{P}$ recovery in the next stage. Though AWBs in both natural and modified forms can be used for P removal, the low $\mathrm{P}$ uptake capacity of raw AWBs hinders their widespread application. In contrast, satisfactory adsorption behaviors can be obtained with AWBs modified by metal loading, $-\mathrm{NH}_{2}$ groups grafting, and thermal activation. However, this should be applied with caution, due to possible side effects. While several mechanisms are reported for the sorption of $\mathrm{PO}_{4}{ }^{3-}$ onto $\mathrm{AWBs}$ (e.g. ion exchange, ligand exchange, chemisorption, surface precipitation, and diffusion), it is found that desorption of $\mathrm{PO}_{4}{ }^{3-}$ from spent AWBs can be largely attributed to anionexchange mechanism. Of influential factors, $\mathrm{pH}$ appears to play the most important role. In many cases, AWBs demonstrated the ability to remove $\mathrm{PO}_{4}{ }^{3-}$ efficiently in a 
short time $(<1 \mathrm{~h})$, in the presence of interfering anions, over a wide $\mathrm{pH}$ range (4-9). These properties provide favorable conditions for their practical applications. The adsorbed P could be desorbed by distilled water, salts, acids, bases. Distilled water and neutral salts are proven to be effective as long as ion exchange mechanism dominates. Conversely, when other mechanisms can be important pathways, acids or bases should be used alternatively. The $\mathrm{P}$ recovery process is in its initial stage of development. It can be done via a combination of $\mathrm{P}$ separation using AWBs and $\mathrm{P}$ precipitation/crystallization using $\mathrm{Ca}(\mathrm{OH})_{2} / \mathrm{CaCl}_{2}$. Off these, the first step can be successfully accomplished through adsorption onto AWBs.

Although significant efforts had been contributed to make progress in the removal and recovery of $\mathrm{PO}_{4}{ }^{3-}$ by $\mathrm{AWBs}$, there are still many points for future research as follows:

1. Further improve modification methods that currently exist in the directions of cost saving, effectiveness, and environmental friendliness. This can be done via examining various quaternizing reagents and combined loading metals;

2. Keep searching for novel potential AWBs in view of practical application, which should have favorable physical properties, less harmful effects, low cost, abundant availability in addition to high affinity and selectivity towards $\mathrm{PO}_{4}{ }^{3-a n i o n s ;}$

3. Developing a systematic and comprehensive method with essential tools to better understand mechanisms of adsorption and desorption;

4. Examining potential AWBs in the column mode on the real wastewater to promote large-scale application of these biosorbents; and

5. Employing potential AWBs in the $\mathrm{PO}_{4}{ }^{3-}$ recovery process at the pilot and full scales. Further work in this matter includes process optimization, product quality improvement, simultaneous recovery of other resources, cost-benefit analysis, field trials, etc.

As a final remark, the adsorptive removal and recovery of $\mathrm{PO}_{4}{ }^{3-}$ from water and wastewater using AWBs can provide a sustainable, efficient, beneficial solution for P management. Thus, it should be considered as a promising green technology. However, the above challenges need to be addressed before ready-to-use recycled $\mathrm{P}$ products can be achieved.

\subsection{References}

Adam, C. (2011). "Case study: Phosphorus recovery from sewage sludge - Results of the European FP6- and FP7-projects SUSAN and SUSYPHOS." International Conference on Environmental (Bio)Technologies and EU-FP7 Environment Brokerage Event, 5-8 September, Gdańsk, Pomeranian, Poland.

Anirudhan, T. S., Noelin, B. F., and Manohar, D. M. (2006). "Phosphate removal from wastewaters using a weak anion exchanger prepared from a lignocellulosic residue." Environmental Science \& Technology, 40, 2740-2745. 
Anirudhan, T. S., and Senan, P. (2011). "Adsorption of phosphate ions from water using a novel cellulose based adsorbent." Journal of Chemical Ecology, 27(2), $147-164$.

Benyoucef, S., and Amrani, M. (2011). "Adsorption of phosphate ions onto low cost Aleppo pine adsorbent." Desalination, 275, 231-236.

Bhojappa, S. (2009). Removal of phosphorus/ selenium from aqueous solution by adsorption processes, Master Thesis, West Virginia University, Morgantown, West Virginia.

Biswas, B. K., Inoue, K., Ghimire, K. N., Ohta, S., Harada, H., Ohto, K., and Kawakita, H. (2007). "The adsorption of phosphate from an aquatic environment using metal loaded orange waste." Journal of Colloid and Interface Science, 312, 214-223.

Biswas, B. K. (2008).Removal and recovery of arsenic and phosphorus by means of adsorption onto orange waste, an available agricultural by-product, Doctoral Dissertation, Saga University, Japan.

Bottini, A., and Rizzo, L. (2012). "Phosphorus recovery from urban wastewater treatment plant sludge liquor by ion exchange." Separation Science and Technology, 47, 613-620.

Boujelben, N., Bouzid, J., Elouear, Z., Feki, M., Jamoussi, F., and Montiel, A. (2008). "Phosphorous removal from aqueous solution using iron coated natural and engineered sorbents." Journal of Hazardous Materials, 151, 103-110.

Carvalho, W. S., Martins, D. F., Gomes, F. R., Leite, I. R., Silva, L. G., Ruggiero, R., and Richter, E. M. (2011). "Phosphate adsorption on chemically modified sugarcane bagasse fibres.” Biomass Bioenergy, 35, 3913-3919.

Chen, W. T., Lin, C. W., Shih, P. K., and Chang, W. L. (2012). "Adsorption of phosphate into waste oyster shell: Thermodynamic parameters and reaction kinetics." Desalination Water Treatment, 47(1-3), 86-95.

Cheng, X., Wang, Y., Sun, Z., Sun, D., and Wang, A. (2013). "Pathways of phosphate uptake from aqueous solution by ZnAl layered double hydroxides." Water Science and Technology, 67(8), 1757-1763.

Choi, J., Lee, S., Park, K., Lee, K., Kim, D., and Lee, S. (2011). "Investigation of phosphorus removal from wastewater through ion exchange of mesostructure based on inorganic material." Desalination, 266, 281-285.

Choi, J., Lee, S., Lee, S., Kim, J., Park, K., Kim, D., and Hong, S. (2012). "Comparison of surface modified adsorbents for phosphate removal in water." Water Air \& Soil Pollution, 223, 2881-2890.

Cornel, P., and Schaum, C. (2009). "Phosphorus recovery from wastewater: needs, technologies and costs." Water Science and Technology, 59(6), 1069-1076.

Cornel, P., Meda, A., and Bieker, S. (2011). Chapter 4.12 Wastewater as a source of energy, nutrients, and service water, Treatise on Water Science, Vol. 4, Elsevier, Oxford, UK.

De Lima, A. C. A., Nascimento, R. F., de Sousa, F. F., Filho, J. M., and Oliveira, A. C. (2012). "Modified coconut shell fibers: A green and economical sorbent for the removal anions from aqueous solutions." Chemical Engineering Journal, $185-186,274-284$. 
Eberhardt, T. L., and Min, S. H. (2008). "Biosorbents prepared from wood particles treated withanionic polymer and iron salt: Effect of particle size on phosphate adsorption." Bioresource Technology, 99, 626-630.

Ebie, Y., Kondo, T., Kadoya, N., Mouri, M., Maruyama, O., Noritake, S., Inamori, Y., and $\mathrm{Xu}, \mathrm{K}$. (2008). "Recovery oriented phosphorus adsorption process in decentralized advanced Johkasou." Water Science and Technology, 57(12), 1977-1981.

Eljamal, O., Okawauchi, J., Hiramatsu, K., and Harada, M. (2013). "Phosphorus sorption from aqueous solution using natural materials." Environmental Earth Sciences, 68, 859-863.

Everglades hub (2013). Phosphorous removal technologies, available at http://www. evergladeshub.com/okeechobee/P.htm. (Accessed on January 14, 2013).

Garcia-Belinchon, C., Rieck, T., Bouchy, L., Gali, A., Rouge, P., and Fabregas, C. (2013). "Struvite recovery: pilot scale results and economic assessment of different scenarios." Water Practice \& Technology, 8(1), 119-130.

Green, C. J., Johnson, P., Allen, V. G., and Crossland, S. L. (2004). Treatment technologies for phosphorus removal from water derived from cattle feedyards, available at http://www.tcfa.org/Research/92 treatment technologies green.pdf. (Accessed on September 25, 2013).

Han, J. S., Min, S., and Kim, Y. (2005). "Removal of phosphorous using AMD-treated lignocellulosic material." Forest Products Journal, 55(11), 48-53.

Hanrahan, G., Salmassi, T. M., Khachikian, C. S., and Foster, K. L. (2005). "Reduced inorganic phosphorus in the natural environment: significance, speciation and determination." Talanta, 66(2), 435-444.

Hu, C., Zhang, T. C., Huang, Y. H., Dahab, M. F., and Surampalli, R. Y. (2005). "Effects of long-term wastewater application on chemical properties and phosphorus adsorption capacity in soils of a wastewater land treatment system." Environ. Sci. Technol., 39(18), 7240-7245.

Huang, M., Yu, Y., and Wu, R. (2010). "Researches on the treatment of phosphorous wastewater with oyster shells." Chinese Journal of Structural Chemistry, 29(12), 1886-1892.

Huang, X., Liao, X., and Shi, B. (2009). "Adsorption removal of phosphate in industrial wastewater by using metal loaded skin split waste." Journal of Hazardous Materials, 166, 1261-1265.

Ismail, Z. Z. (2012). "Kinetic study for phosphate removal from water by recycled date-palm wastes as agricultural by-products." International Journal of Environmental Studies, 69(1), 135-149.

Jeon, D. J., and Yeom, S. H. (2009). "Recycling wasted biomaterial, crab shells, as an adsorbent for the removal of high concentration of phosphate." Bioresource Technology, 100, 2646-2649.

Jiang, C., Jia, L., He, Y., Zhang, B., Kirumba, G., and Xie, J. (2013). "Adsorptive removal of phosphorous from aqueous solution using sponge iron and zeolite." Journal of Colloid and Interface Science, 402, 246-252. 
Jutidamrongphan, W., Park, K. Y., Dockko, S., Choi, J. W., and Lee, S. H. (2012). "High removal of phosphate from wastewater using silica sulphate." Environmental Chemistry Letters, 10, 21-28.

Jyothi, M. D., Kiran, K. R., and Ravindhranath, K. (2012). "Phosphate pollution control in waste waters using new biosorbents." International Journal of Water Resources and Environmental Engineering, 4(4), 73-85.

Kalmykova, Y., and Fedje, K. (2013). "Phosphorus recovery from municipal solid waste incineration fly ash." Waste Management, 33, 1403-1410.

Karachalios, A. P. (2012). Nutrient removal from water by various quaternized wood agricultural residues using a choline based ionic liquid analogue, Doctoral Dissertation, Stevens Institute of Technology, Hoboken, New Jersey.

Karimaian, K. A., Amrane, A., Kazemian, H., and Panahi, R. (2013). "Retention of phosphorous ions on natural and engineered waste pumice: Characterization, equilibrium, competing ions, regeneration, kinetic, equilibrium and thermodynamic study." Applied Surface Science, 284, 419-431.

Karthikeyan, K. G., Tshabalala, M. A., Wang, D., and Kalbasi, M. (2004). "Solution chemistry effects on orthophosphate adsorption by cationized solid wood residues." Environmental Science \& Technology, 38(3), 904-911.

Karthikeyan, K. G., Tshabalala, M. A., and Grad, D. W. (2002). "Use of lignocelluloses materials for sorption media for phosphorus removal." $A S A E$ Annual International Meeting, July 28-31, Chicago, Illinois.

Kose, T. E., and Kivanc, B. (2011). "Adsorption of phosphate from aqueous solutions using calcined waste eggshell.” Chemical Engineering Journal, 178, 34-39.

Krishnan, K. A., and Haridas, A. (2008). "Removal of phosphate from aqueous solutions and sewage using natural and surface modified coir pith." Journal of Hazardous Materials, 152, 527-535.

Kumar, P., Sudha, S., Chand, S., and Srivastava, V. C. (2010). "Phosphate removal from aqueous solution using coir pith activated carbon." Separation Science and Technology, 45, 1463-1470.

Kuzma, M. (2011). Phosphorus removal and recovery in wastewater: How far can we go? Available at http://www.azwater.org/common/files/committees/e8fbf236e225-4d3b-8e17-d94ae7beb19d/Matt\%20Kuzma\%20-\%20Phosphorus\%20Remo val $\% 20$ and $\% 20$ Reocvery $\% 20$ from $\% 20$ Wastewater $\% 20$ Oct $\% 202$ nd $\% 202011$.pdf. (Accessed on September 19, 2013).

Li, H., Ru, J., Yin, W., Liu, X., Wang, J., and Zhang, W. (2009). "Removal of phosphate from polluted water by lanthanum doped vesuvianite." Journal of Hazardous Materials, 168, 326-330.

Li, R., Kelly, C., Keegan, R., Xiao, L., and Morrison, L. (2013). "Phosphorous removal from wastewater using natural pyrrhotite." Colloids and Surfaces A, 427, $13-18$.

Li, Y. J., Wang, L. H., and Lan, Y. Z. (2009). "Experimental study on phosphorous removal by activated alumina adsorbents." Journal Kunming Metallurgy College, $25,59-65$. 
Liu, J., Wan, L., Zhang, L., and Zhou, Q. (2011). "Effect of pH, ionic strength, and temperature on the phosphate adsorption onto lanthanum doped activated carbon fiber." Journal of Colloid and Interface Science, 364, 490-496.

Liu, T., Wu, K., and Zeng, L. (2012). "Removal of phosphorus by a composite metal oxide adsorbent derived from manganese ore tailings." Journal of Hazardous Materials, 217-218, 29-35.

Loganathan, P., Vigneswaran, S., Kandasamy, J., and Bolan, N. S. (2014). "Removal and recovery of phosphate from water using sorption." Critical Reviews in Environmental Science and Technology, 44(8), 847-907.

Mallampati, R., and Valiyaveettil, S. (2013). "Apple peel-a versatile biomass for water purification." ACS Applied Materials and Interfaces, 5, 4443-4449.

Molinos-Senante, M., Hernandez-Sancho, F., Sala-Garrido, R., Garrido-Baserba, M. (2011). "Economic feasibility study for phosphorus recovery processes." Ambio, 40, 408-416.

Marshall, W. E., and Wartelle, L. H. (2004). "An anion exchange resin from soybean hulls." Journal of Chemical Technology and Biotechnology, 79, 1286-1292.

Meng, S., Li, Y., Zhang, T., Chen, J., Xu, P., Song, C., Fan, L., and Qiu, L. (2013). "Influences of environmental factors on lanthanum/aluminium modified zeolite adsorbent for phosphorous adsorption from wastewater." Water, Air, \& Soil Pollution, 224, 1556-1564.

Mezenner, N. Y., and Bensmaili, A. (2009). "Kinetics and thermodynamic study of phosphate adsorption on iron hydroxide eggshell waste." Chemical Engineering Journal, 147, 87-96.

Midorikawa, I., Aoki, H., Omori, A., Shimizu, T., Kawaguchi, Y., Kassai, K., and Murakami, T. (2008). "Recovery of high purity phosphorus from municipal wastewater secondary effluent by a high-speed adsorbent." Water Science and Technology, 58(8), 1601-1607.

Namasivayam, C., Sakoda, A., and Suzuki, M. (2005). "Removal of phosphate by adsorption onto oyster shell powder - kinetic studies." Journal of Chemical Technology and Biotechnology, 80(3), 356-358.

Namasivayan, C., and Sangeetha, D. (2004). "Equilibrium and kinetic studies of adsorption of phosphate onto $\mathrm{ZnCl}_{2}$ activated coir pith carbon." Journal of Colloid and Interface Science, 280, 359-365.

Nada, A. M. A., and Hassan, M. L. (2006). "Ion exchange properties of carboxylated bagasse." Journal of Applied Polymer Science, 102, 1399-1404.

Nieminen, J. (2010).Phosphorus recovery and recycling from municipal wastewater sludge, Master Thesis, Aalto University, Espoo, Finland.

Ning, P., Bart, H., Li, B., Lu, X., and Zhang, Y. (2008). "Phosphate removal from wastewater by model La(III) zeolite adsorbents." Journal of Environmental Sciences, 20, 670-674.

Neethling, J. B. (2011). Impact of Phosphorous Removal to Low Limits, available at http://www.azwater.org/common/files/committees/e8fbf236-e225-4d3b-8e17-d9 4ae7beb19d/Phosphorus\%202.pdf. (Accessed on January 20, 2013). 
Nguyen, T. A. H., Ngo, H. H., Guo, W. S., and Nguyen, T. V. (2012). "Phosphorus removal from aqueous solutions by agricultural by-products: A critical review." Journal of Water Sustainability, 2(3), 193-207.

Ogata, F., Tominaga, H., Kangawa, M., Inoue, K., and Kawasaki, N. (2012). "Characteristics of granular boehmite and its ability to adsorb phosphate from aqueous solution." Chemical \& Pharmaceutical Bulletin, 60(8), 985-988.

Ohura, S., Harada, H., Biswas, B. K., Kondo, M., Ishikawa, S., Kawakita, H., Ohto, K., and Inoue, K. (2011). "Phosphorus recovery from secondary effluent and side stream liquid in a sewage treatment plant using zirconium loaded saponified orange waste." Journal of Material Cycles and Waste Management, 13, 293-297.

Peleka, E. N., and Deliyanni, E. A. (2009). "Adsorptive removal of phosphates from aqueous solutions." Desalination, 245, 357-371.

Peng, F., He, P., Luo, Y., Lu, X., Liang, Y., and Fu, J. (2012). “Adsorption of phosphate by biomass char deriving from fast pyrolysis of biomass waste." CLEAN - Soil, Air, Water, 40(5), 493-498.

Penn, C. J., Bryant, R. B., Kleinman, P. J. A., and Allen, A. L. (2007). "Removing dissolved phosphorus from drainage ditch water with phosphorus sorbing materials." Journal of Soil and Water Conservation, 62, 269-276.

Ren, Z., Shao, L., and Zhang, G. (2012). "Adsorption of phosphate from aqueous solution using an iron-zirconium binary oxide sorbent." Water, Air, \& Soil Pollution, 223, 4221-4231.

Riahi, K., Thayer, B. B., Mammou, A. B., and Ammar, A. B. (2009). "Biosorption characteristics of phosphates from aqueous solution onto Phoenix dactylifera L. date palm fibers" Journal of Hazardous Materials, 170, 511-519.

Rodrigues, L. A., Maschio, L. J., Coppio, L. S. C., Thim, G. P., and Silva, M. L. C. P. (2012). "Adsorption of phosphate from aqueous solution by hydrous zirconium oxide." Environmental Technology, 33(12), 1345-1351.

Sartorius, C., Horn, J. V., and Tettenborn, F. (2012). "Phosphorus recovery from wastewater-expert survey on present use and future potential." Water Environment Research, 84(4), 313-322.

Schick, J., Kratz, S., Adam, C., and Schnug, E. (2009). "Techniques for P recovery from wastewater and sewage sludge and fertilizer quality of $\mathrm{P}$ recycling products." Phosphorus Recycling Conference in Berlin, available at http://www. mmm.fi/attachments $/ \mathrm{mmm} / \mathrm{ministerio} / 5 \mathrm{n} 8 \mathrm{~h} 6 \times \mathrm{xg} 9 \mathrm{~T} / \mathrm{presentation}$ judith schick.pd f. (Accessed on September 14, 2013).

Shin, E. W., Karthikeyan, K. G., and Tshabalala, M. A. (2005). "Ortho phosphate sorption onto lanthanum treated lignocellulosic sorbents." Environmental Science \& Technology, 39, 6273-6279.

Srivastava, S., and Goyal, P. (2010). Novel biomaterials, decontamination of toxic metals from wastewater, Springer, Heidelberg.

Tian, S., Jiang, P., Ning, P., and Su, Y. (2009). "Enhanced adsorption removal of phosphate from water by mixed lanthanum/aluminium pillared montmorillonite." Chemical Engineering Journal, 151, 141-148. 
Tshabalala, M. A., Karthikeyan, K. G., and Wang, D. (2004). "Cationized milled pine bark as an adsorbent for orthophosphate anions." Journal of Applied Polymer Science, 93, 1577-1583.

Tyagi, V. K., and Lo, S. (2013). "Sludge: a waste or renewable source for energy and resources recovery." Renewable \& Sustainable Energy Reviews, 25, 708-728.

Unnithan, M. R., Vinod, V. P., and Anirudhan, T. S. (2002). "Ability of iron(III)-loaded carboxylated polyacrylamide-grafted sawdust to remove phosphate ions from aqueous solution and fertilizer industry wastewater: Adsorption kinetics and isotherm studies." Journal of Applied Polymer Science, 84(13), 2541-2553.

Wang, W., Yue, Q., Xu, X., Gao, B., Zhang, J., Li, Q., and Xu, J. (2010). “Optimized conditions in preparation of giant reed quaternary amino anion exchanger for phosphate removal." Chemical Engineering Journal, 157, 161-167.

Wang, Z., Nie, E., Li, J., Yang, M., Zhao, Y., Luo, X., and Zheng, Z. (2012). "Equilibrium and kinetics of adsorption of phosphate onto iron doped activated carbon.” Environmental Science and Pollution Research, 19, 2908-2917.

Wang, S., Yuan, R., Yu, X., and Mao, C. (2013). "Adsorptive removal of phosphate from aqueous solutions using lead-zinc tailings." Water Science and Technology, 67(5), 983-988.

Wartelle, L. H., and Marshall, W. E. (2006). "Quaternized agricultural by-products as anion exchange resins." Journal of Environmental Management, 78, 157-162.

Xu, X., Gao, B., Wang, W., Yue, Q., Wang, Y., and Ni, S. (2009). "Adsorption of phosphate from aqueous solutions onto modified wheat residue: Characteristics, kinetic and column studies." Colloids and Surfaces B, 70, 46-52.

$\mathrm{Xu}, \mathrm{X} .$, Gao, B., Yue, Q., and Zhong, Q. (2010). "Preparation of agricultural by-product based anion exchanger and its utilization for nitrate and phosphate removal." Bioresource Technology, 101, 8558-8564.

Xu, X., Gao, B., Yue, Q., and Zhong, Q. (2011a). "Sorption of phosphate onto giant reed based adsorbent: FTIR, Raman spectrum analysis and dynamic sorption/ desorption properties in filter bed." Bioresource Technology, 102, 5278-5282.

Xu, X., Gao, B., Tan, X., Zhao, Y., Yue, Q., and Wang, Y. (2011b). "Characteristics of diethylenetriamine-crosslinked cotton stalk/ wheat stalk and their biosorption capacitites for phosphate." Journal of Hazardous Materials, 192(3), 1690-1696.

Xu, X., Gao, B., Yue, Q., Zhong, Q., and Li, Q. (2011c). "Preparation of new types of anion exchange resins from agricultural by-products and their utilization in the removal of various toxic anions from solutions." Chemical Engineering Journal, 167, 104-111.

Yan, L., Xu, Y., Yu, H., Xin, X., Wei, Q., and Du, B. (2010). “Adsorption of phosphate from aqueous solution by hydroxyl aluminium, hydroxyl iron and hydroxyl iron aluminium pillared bentonites." Journal of Hazardous Materials, $179,244-250$.

Yeom, S. H., and Jung, K. (2009). "Recycling wasted scallop shell as an adsorbent for the removal of phosphate." Journal of Industrial and Engineering Chemistry, 15(1), 40-44. 
Yu, S., Dong, X., Gong, H., Jiang, H., and Liu, Z. (2012). "Adsorption kinetic and thermodynamic studies of phosphate onto tantalum hydroxide." Water Environment Research, 84(12), 2115-2122.

Yue, Q., Wang, W., Gao, B., Xu, X., Zhang, J., and Li, Q. (2010). "Phosphate removal from aqueous solution by adsorption on modified giant reed." Water Environment Research, 82(4), 374-381.

Zhang, T. C., Dahab, M. F., Nunes, G., Hu, C., and Surampalli, R. Y. (2007). "Phosphorus fate and transport in soil columns loaded intermittently with influent of high phosphorus concentrations." Water Environ. Res., 79, 2343-2351.

Zhang, G., Liu, H., Liu, R., and Qu, J. (2009). "Removal of phosphate from water by a Fe-Mn binary oxide adsorbent." Journal of Colloid and Interface Science, 335, $168-174$.

Zhang, L., Wan, L., Chang, N., Liu, J., Duan, C., Zhou, Q., and Li, X. (2011). "Removal of phosphate from water by activated carbon fiber loaded with lanthanum oxide." Journal of Hazardous Materials, 190, 848-855.

Zhang, J., Shan, W., Ge, J., Shen, Z., Lei, Y., and Wang, W. (2012). "Kinetic and equilibrium studies of liquid phase adsorption of phosphate on modified sugarcane bagasse.” Journal of Environmental Engineering, 138(3), 252-258. 